\title{
The Role of Barite in the Post-Mining Stabilization of Radium-226: A Modeling Contribution for Sequential Extractions
}

\author{
Clémence Besançon ${ }^{1,2, *}$, Camille Chautard ${ }^{1}$, Catherine Beaucaire ${ }^{3}$, Sébastien Savoye ${ }^{4}$, \\ Paul Sardini ${ }^{5}\left[\right.$, Martine Gérard ${ }^{2}$ and Michael Descostes ${ }^{1}(\mathbb{C}$ \\ 1 R\&D Department, ORANO Mining, 92320 Chatillon, France; camille.chautard@orano.group (C.C.); \\ michael.descostes@orano.group (M.D.) \\ 2 Institut de minéralogie, de physique des matériaux et de cosmochimie (IMPMC), CNRS UMR7590, MNHN, \\ IRD, Sorbonne Université, F-75005 Paris, France; martine.gerard@sorbonne-universite.fr \\ 3 Independent Researchers, 21540 Chevannay, France; catherine.beaucaire@free.fr \\ 4 Des, Service d'Etude du Comportement des Radionucléides (SECR), CEA, Université Paris-Saclay, \\ F-91191 Gif-sur-Yvette, France; sebastien.savoye@cea.fr \\ 5 Institut de Chimie des Milieux et des Matériaux de Poitiers (IC2MP), Université de Poitiers, CEDEX 9, \\ Poitiers 86073, France; paul.sardini@univ-poitiers.fr \\ * Correspondence: clemence.besancon@orano.group
}

Received: 15 April 2020; Accepted: 27 May 2020; Published: 29 May 2020

\begin{abstract}
Barite is ubiquitous and known to incorporate ${ }^{226}$ Ra through the formation of a solid-solution. In U mining mill tailings, barite is one of the dominant sulfate-binding minerals. In such environments, sequential extractions are generally used to identify the U- and ${ }^{226}$ Ra-binding phases and their associated reactivity. To better decipher the main processes governing the behavior of ${ }^{226} \mathrm{Ra}$ during such sequential extractions, a geochemical model was developed with PHREEQC mimicking the sequential extraction of $U$ and ${ }^{226} \mathrm{Ra}$ from Bois-Noirs Limouzat $\mathrm{U}$ mine tailings, France. The model results were compared with a dataset produced by an experimental sequential extraction from the same mine tailings and including data on the solids and selective extraction results with the major elements, $\mathrm{U}$ and ${ }^{226} \mathrm{Ra}$. The simulations reproduced the results of the experimental chemical extractions accurately, with iron oxyhydroxides being the major U binding phase. However, the modeling indicated rather that barite would be the main ${ }^{226} \mathrm{Ra}$ binding phase, instead of the iron oxyhydroxides identified by the experimental extractions. This is consistent with the ${ }^{226} \mathrm{Ra}$ concentration measured in pore water, but in disagreement with the direct interpretation of the sequential extractions. The direct interpretation disregarded the role of barite in the geochemical behavior of ${ }^{226}$ Ra because barite was not specifically targeted by any of the extraction steps. However, the modeling showed that the dissolution of ${ }^{226}$ Ra-binding barite by reactants would lead to a ${ }^{226}$ Ra redistribution among the clay minerals, resulting in a skew in the experimental results. Similar results were achieved by referring simply to the bulk mineralogy of the tailings. This study highlights the importance of considering the mineralogy, mineral reactivity and retention capacity for more realistic interpretation of sequential extractions. Moreover, this paper provides new perspectives on the long-term consequences of these mill tailings in which barite controls the geochemical behavior of the ${ }^{226} \mathrm{Ra}$.
\end{abstract}

Keywords: sequential extractions; $\mathrm{U}$ and ${ }^{226}$ Ra modeling; barite; uranium mill tailings

\section{Introduction}

Most environmental studies aim to understand the mobility of the chemical elements and their environmental and human health risk. Such studies require (i) the analysis of the chemistry of solutions 
and the reactivity of solids and (ii) the linking of the in situ observations to experimental results and models [1-4]. The sequential extraction technique allows for the characterization of the binding phases and the retention capacity (solubility of phase, sorption, coprecipitation) of an element of interest in a solid sample. This is achieved through the successive use of specific reactants. Theoretically, the content of the leachate corresponds to the quantity of the targeted binding phase in the solid sample [5]. However, some authors mentioned various disadvantages of this technique. The main question about sequential extractions is whether they give information on the reactivity of the species under a certain chemical environment or actually allow the identification of the binding phases. The attribution of the element of interest to a specific solid form has to be confirmed by complementary analyses [6-10] such as mineralogy, solid, water and leachate chemistry, and the sample's history. Distortion of the results may be caused by (i) the possible re-distribution of the elements of interest between the mineral phases during extraction [7,11], (ii) the non-selectivity of reagents for the target phases [5], (iii) incomplete extraction of a binding phase [12,13] and (iv) mineral neoformation during extraction [14]. Another drawback is the wide variety of existing protocols related to the type of samples. This results in a variety of reactants, reaction time, solid/liquid ratio and number of extracting steps [15,16], making cross-comparison difficult. For example, Figure S1 in Supplementary Materials shows that when comparing 25 sequential extraction studies, the liquid to solid ratio values varied from 6 to $100 \mathrm{~mL} / \mathrm{g}[2-4,6-9,12,15-26])$. An important experimental constraint is also the number of replicates required, making this technique time consuming.

Radium-226 is the predominant radionuclide in terms of activity of most Naturally Occurring Radioactive Material (NORM) waste [27]; it belongs to the decay chain of ${ }^{238} \mathrm{U}$, the most abundant isotope of $U$ in natural materials (99.27\% of $U$ isotopes by mass) [28]. ${ }^{226}$ Ra's half-life of 1600 years makes it the most relevant radium isotope to study for environmental processes. ${ }^{226} \mathrm{Ra}$ is an alpha emitter with a high specific activity $\left(3.7 \times 10^{10} \mathrm{~Bq} / \mathrm{g}\right)$ [29]. This is an issue for $\mathrm{U}$ mining, and also for other extractive industries such as coal mining [27,30], the production of phosphate fertilizers [27] and of non-conventional oil and gas $[3,17,23,31]$. U-bearing ore usually presents ${ }^{226}$ Ra in secular equilibrium with ${ }^{238} \mathrm{U}$ because most $\mathrm{U}$ mineralization is older than 1.5 million years [32-35]. The $\mathrm{U}$ extraction process by leaching specifically targets $U$, creating a strong ${ }^{238} U /{ }^{226}$ Ra disequilibrium. Almost all the $\mathrm{Ra}$ and the other daughter elements of $U$ end up in the residues and are stored in the tailings [36,37].

${ }^{226} \mathrm{Ra}$ is an ultra-trace element: $0.5-20 \mathrm{mBq} / \mathrm{L}$ in environmental water (from $6.10^{-17}$ to $2.10^{-15} \mathrm{~mol} / \mathrm{L}$ ), reaching up to $3000 \mathrm{mBq} / \mathrm{L}\left(4.10^{-13} \mathrm{~mol} / \mathrm{L}\right)$ at $\mathrm{U}$ mining sites [38]. These concentrations do not allow for pure radium phases to precipitate. ${ }^{226} \mathrm{Ra}^{\prime} \mathrm{s}$ chemistry is controlled by co-precipitation with other elements or by adsorption. The U-bearing minerals contain ${ }^{226}$ Ra produced by the decay of ${ }^{238} U[18,39]$. ${ }^{226} \mathrm{Ra}$ adsorption occurs on clay minerals [40-42], iron and manganese oxyhydroxides [36,43,44], and organic matter [45]. As for other alkaline earth elements, ${ }^{226} \mathrm{Ra}$ forms solid solutions, mostly sulfate minerals where ${ }^{226} \mathrm{Ra}$ substitutes for another alkali earth [46,47]. ${ }^{226} \mathrm{Ra}$ has close physicochemical properties to $\mathrm{Ba}$ (in terms of ionic radii, ionization potential and electronegativity, for example [39]). The most active solid-solution trap for ${ }^{226} \mathrm{Ra}$ in the environment is barite, forming a $(\mathrm{Ba}, \mathrm{Ra}) \mathrm{SO}_{4}$ solid-solution $[46,48,49]$. Today, some $U$ mine mill processes add barium chloride at the end of the $U$ extraction to fix ${ }^{226} \mathrm{Ra}$ in insoluble barite [37]. Some studies have also shown the importance of barite in the control of ${ }^{226} \mathrm{Ra}$ concentrations in natural systems [50,51]. Barite is ubiquitous in $\mathrm{U}$ granitic ores and in U mill tailings [37,52-54]. Ba concentrations increase with the weathering of silicate rocks, and the sulfuric acid mill treatment add massive quantities of sulfates into the system thereby promoting barite neoformation [1]. Barite is insoluble in most reactants $(\log (\mathrm{Ks})=9.97)$ [55]; barite is usually considered to remain in the residual solid of the sequential extractions [56]. No sequential extractions have been developed to specifically target barite, despite its imperfect recovery yield [57,58]. Benĕs et al. [5] noted the partial dissolution of barite by the reactants during a sequential extraction procedure when barite quantities were small.

${ }^{226} \mathrm{Ra}$ concentrations in solids are too low to be measured by Wavelength-Dispersive X-Ray Spectroscopy (WDS). The detection limit for heavy elements is around $10 \mathrm{ppm}[59,60]$, i.e., $5 \times 10^{5} \mathrm{~Bq} / \mathrm{g}$ 
of ${ }^{226} \mathrm{Ra}$, far above the activities found in environmental samples. Sequential extractions are therefore deemed necessary for the study of ${ }^{226} \mathrm{Ra}$; its concentration in leachate being determined either by High Resolution Inductively Coupled Plasma Mass Spectroscopy (HR-ICP-MS) or techniques using its decay emissions. Many studies have used sequential extractions to localize Ra $[5,61] .{ }^{226} \mathrm{Ra}$ was usually reported mainly in the residual phase $[3,9,13,17,62]$, but also with high extraction rates $(>10 \%$ of the total ${ }^{226} \mathrm{Ra}$ ) in the soluble fraction $[17,18]$, the exchangeable fraction (adsorbed on clay minerals surfaces) $[9,63]$, the organic matter fraction [13,63], the reducible (Fe and Mn oxides) fraction $[4,8]$ and the carbonate fraction [3]. Some conclusions clearly contradict each other $[48,52,64,65]$. Indeed, as an ultra-trace element, $\mathrm{Ra}$ is capable of exacerbating some issues of sequential extractions relating to the redistribution of the element or the need of a proper identification of the binding phase present.

All of these issues regarding sequential extractions and the localization of ${ }^{226} \mathrm{Ra}$ in binding phases such as barite have led to the construction of a geochemical model using PHREEQC [66], mimicking some sequential extraction experiments used to target ${ }^{226} \mathrm{Ra}$ on samples from $\mathrm{U}$ mill tailings. A complete experimental dataset recently acquired by Chautard et al. [22] was used, including data on the solid, and selective extractions results on the major elements and also $U$ and ${ }^{226} \mathrm{Ra}$. Test models were performed to evaluate the reactivity of the minerals involved in ${ }^{226} \mathrm{Ra}$ retention with the reactants used during sequential extractions. Then, sequential extraction of $U$ and ${ }^{226} \mathrm{Ra}$ from $U$-mine mill tailings was modeled using the experimental data of Chautard et al. [22]. The model was used to monitor the behavior of major cations and $U$, which are well understood, to assess its robustness. It was then applied to ${ }^{226} \mathrm{Ra}$.

The objectives of this numerical modeling study are to compare the results obtained by calculations which consider thermodynamic equilibria (solubility and sorption) with the experimental data, but also to complement the experimental data with additional information generated by the model's outputs and intermediary calculations. The main objective is to better identify the main processes governing the behavior of ${ }^{226} \mathrm{Ra}$ during such sequential extractions so as to determine the possible ${ }^{226} \mathrm{Ra}$ binding phases. To the authors' knowledge, the present study is the first to draw on experimental data to model a sequential extraction procedure on tailings by considering a combination of solid mineralogy, sorption, solubility and aqueous complexation. This approach may be used for other extraction schemes targeting ${ }^{226} \mathrm{Ra}$ in a medium containing barite, and also to provide a better understanding of the results of sequential extractions targeting other trace elements.

\section{Materials and Methods}

\subsection{An Example of Sequential Extractions Targeting $U$ and ${ }^{226} R a$ in Mill Tailings}

\subsubsection{Study on Bois Noirs Limouzat Tailings}

The Bois Noirs Limouzat site (BNL), located in the Forez region of France, is a former U mine, which operated from 1959 to 1980 . The ore treatment process involved a chemical treatment with sulfuric acid to leach the $\mathrm{U}$. There was a total of 1.3 million tons of tailings, which includes $\mathrm{U}$ $\left(205 \mathrm{ppm}-8.6 \times 10^{-4} \mathrm{~mol} / \mathrm{kg}\right.$ ) and ${ }^{226} \mathrm{Ra}(47 \mathrm{~Bq} / \mathrm{g})$ (mean concentrations). Tailings were stored under a water cover (acting as radiological protection) in a basin. The BNL site is subject to environmental monitoring and respects French environmental standards. These concentrations are the result of chemical equilibria between the water and the tailings.

In the tailings, a sandy silty facies and a clayey silty facies were identified in relation to the $U$ milling process. In order to localize both $\mathrm{U}$ and ${ }^{226} \mathrm{Ra}$, and predict their retention under current storage conditions, a detailed characterization (grain size, chemical, mineralogical and radiological characterization) was carried out and completed by sequential extractions for the soluble phases, the exchangeable fraction on the clay minerals, the carbonates and poorly crystallized ferric oxyhydroxides and the crystallized iron oxyhydroxides. This extraction protocol is described in Table 1. The extraction protocol was derived from the literature on sequential extractions for 
$\mathrm{U}$. The basin water undergoes treatment before its discharge into the environment, in particular because the ${ }^{226} \mathrm{Ra}$ concentration (mean concentrations in the basin's water are $2.3 \mathrm{~Bq} / \mathrm{L}$ for ${ }^{226} \mathrm{Ra}$ and $0.06 \mathrm{mg} / \mathrm{L}-2.5 \times 10^{-7} \mathrm{~mol} / \mathrm{L}-$ for U) [67]: it is higher than the waste water local regulation $(0.74 \mathrm{~Bq} / \mathrm{L}[22])$. These data are important to assess the duration of the water treatment.

Table 1. The four steps of the sequential extraction protocol and the reactants used in each step by the experimental (Chautard et al. [22]) and modeling work (this study).

\begin{tabular}{|c|c|c|}
\hline \multirow{2}{*}{ Step } & \multicolumn{2}{|c|}{ Reactant Used } \\
\hline & Experimental Study [22] & Modeling (This Study) \\
\hline 1-targeting soluble phases & $40 \mathrm{~mL}$ deionized water & $\begin{array}{c}40 \mathrm{~mL} \text { pure water in equilibrium } \\
\text { with atmospheric } \mathrm{CO}_{2}\end{array}$ \\
\hline $\begin{array}{l}2 \text {-targeting elements sorbed on } \\
\text { clay minerals }\end{array}$ & $40 \mathrm{~mL} 10^{-2} \mathrm{M} \mathrm{CsCl}$ & $\begin{array}{l}40 \mathrm{~mL} 10^{-2} \mathrm{M} \mathrm{CsCl} \text { solution in } \\
\text { equilibrium with atmospheric } \mathrm{CO}_{2}\end{array}$ \\
\hline $\begin{array}{l}\text { 3-targeting carbonates and } \\
\text { weakly crystallized ferric } \\
\text { oxyhydroxides }\end{array}$ & $\begin{array}{c}40 \mathrm{~mL} \text { solution } \\
1 \mathrm{M} \text { sodium acetate in } 25 \% \text { acetic } \\
\text { acid, } \mathrm{pH}=4\end{array}$ & $\begin{array}{c}40 \mathrm{~mL} \text { solution } \\
\mathrm{pH} \text { fixed at } 4 \\
\text { solution concentrations: } \\
\mathrm{Na}: 1 \mathrm{M} \\
\text { Acetate: } 5.2 \mathrm{M}(1 \mathrm{M} \text { from sodium } \\
\text { acetate, } 4.2 \mathrm{M} \text { from } 25 \% \text { acetic } \\
\text { acid })\end{array}$ \\
\hline $\begin{array}{l}\text { 4-targeting strongly crystallized } \\
\text { ferric oxyhydroxides }\end{array}$ & $\begin{array}{l}40 \mathrm{~mL} \text { solution } \\
\mathrm{NH}_{2} \mathrm{OH} 0.04 \mathrm{M} \text { under the form of } \\
\text { hydroxylamine hydrochloride }+ \\
\text { hydrochloric acid to fix } \mathrm{pH}=2\end{array}$ & $\begin{array}{c}40 \mathrm{~mL} \text { solution } \\
\text { solution concentrations: } \\
\mathrm{Cl}: 0.05 \mathrm{M}(0.04 \mathrm{M} \text { for } \\
\text { hydroxylamine hydrochloride }+ \\
0.01 \mathrm{M} \text { for } \mathrm{HCl} \text { to } \mathrm{pH}=2) \\
\text { Solution in equilibrium with } \mathrm{H}_{2} \\
\text { gas phase fixing } \mathrm{Eh}=-3 \mathrm{~V} / \mathrm{SHE}\end{array}$ \\
\hline
\end{tabular}

This study on BNL tailings is one of the few studies providing the concentrations of the chemical elements released through all stages of the sequential extractions, for both the major elements and the targeted contaminants, as well as the solid chemistry and mineralogy of the samples. These data are usually unavailable, which hinders the possibilities for further modeling and complete understanding.

The present study focuses on modeling the results of these sequential extractions.

\subsubsection{Selection of Samples for this Study}

This study only considered the clayey silty samples C1P3B, C1P5H and C1P11B. These are the most interesting because of their higher concentrations of $U$ (mean concentration of $243.3 \mathrm{ppm}-1.02 \times 10^{-3} \mathrm{~mol} / \mathrm{kg} \mathrm{U}$ ) and ${ }^{226} \mathrm{Ra}$ (mean activity of $64.7 \mathrm{~Bq} / \mathrm{g}$ ) compared to the sandy silty samples. These samples underwent the A (strong) extraction protocol from the Chautard et al. study [22].

\subsubsection{Identification of the Minerals of Interest in the Mineral Assemblage for the Sequential} Extractions Modeling

The mineralogy of the clayey silty samples, determined by X-Ray Diffraction (XRD) and Scanning Electron Microscopy/Energy Dispersive X-ray Spectroscopy (SEM/EDS) characterization [22], consists of the following: primary minerals originating from the granitic ore such as quartz, feldspar, micas and pyrite, and secondary minerals linked to the milling and the weathering of the ore such as clay minerals, gypsum and iron oxyhydroxides. Table 2 summarizes the mineralogy of the clayey silty samples and how it was implemented in the model. 
Table 2. Minerals observed in the clayey silty samples, determined by X-ray diffraction (XRD) and confirmed by Scanning Electron Microscopy/Energy Dispersive X-ray Spectroscopy (SEM/EDS), and the phases considered in the model.

\begin{tabular}{ccc}
\hline Minerals & Observations & As Considered in the Model \\
\hline Primary minerals & $\begin{array}{c}\text { Quartz predominant, K-feldspar } \\
\text { and plagioclases }\end{array}$ & Not considered \\
\hline Clay minerals & Kaolinite, smectite, chlorite & Included as montmorillonite \\
\hline Micas & Biotite, muscovite & Included as montmorillonite \\
\hline Sulfate minerals & Gypsum, barite & Included \\
\hline Sulfides & Partly oxidized pyrites & Included as ferrihydrite \\
\hline Oxides/oxyhydroxides & $\begin{array}{c}\text { Secondary iron oxyhydroxydes: } \\
\text { ferrihydrite and goethite }\end{array}$ & Included as ferrihydrite \\
\hline U-minerals & $\begin{array}{c}\text { Uraninites included in quartz, } \\
\text { apatites, monazites, uranyl } \\
\text { phosphates }\end{array}$ & $\begin{array}{c}\text { Considered as refractory part of U, } \\
\text { not included }\end{array}$ \\
\hline
\end{tabular}

The primary minerals were deemed negligible for the retention of $U$ and ${ }^{226} \mathrm{Ra}$ as they either present weak adsorption and solid solution properties, or are not considered to react during the sequential extractions. The oxidizing conditions of the tailings promote the formation of secondary iron oxyhydroxides, the model calculations therefore neglected pyrite.

Clay minerals, iron oxyhydroxides and barite are known to have a strong influence on the mobility of ${ }^{226} \mathrm{Ra}$, and were included in the model. The first two can adsorb ${ }^{226} \mathrm{Ra}$ while barite can incorporate ${ }^{226} \mathrm{Ra}$ in the form of a solid-solution. SEM/EDS confirmed the presence of barite in the samples as an accessory mineral (see Figure S2 in Supplementary Materials). Montmorillonite is a common clay mineral in granite, and because its sorption capacity is far greater than other clay minerals (cation exchange capacity (CEC) of $0.89 \mathrm{meq} / \mathrm{g}$ for montmorillonite and $0.0563 \mathrm{meq} / \mathrm{g}$ for kaolinite $[68,69]$ ), it was considered that montmorillonite governs the cation retention caused by the clay minerals. This assumption maximizes the role of clay adsorption, which is discussed below. Ferrihydrite, a short-range ordered mineral, is the most common secondary iron oxyhydroxide identified with a high adsorption capacity $[70,71]$. The primary iron oxides are either dissolved during the mill process or are mostly in the form of inclusions [72]. Gypsum is ubiquitous, highly soluble, and formed in substantial quantity because of the lime neutralization. It is of substantial importance in the chemistry of the leachates and could influence the major elements and the reactivity of other minerals through sorption competition on the clay minerals and iron oxyhydroxides.

The assemblage comprising gypsum, montmorillonite, ferrihydrite and barite is the standard mineral assemblage for this study.

\subsection{Development of the Model}

The model aims to complement the experimental data with additional information generated by the model's outputs and intermediary calculations. It is worth noting that the establishment of most thermodynamic constants employed to analyze the geochemical behavior of ${ }^{226} \mathrm{Ra}$ has only happened in recent years.

The PHREEQC software was used [66] to describe the initial equilibrium between the tailings and the pore water, and to model the sequential extraction steps. The modeling was performed using the PRODATA 1.1.0.4 thermodynamic database, especially built for mining applications with an emphasis on $\mathrm{U}$ and $\mathrm{Ra}$ [73]. It was completed with the acetate complexation constants from the Minteq database (minteq.dat 3568 2009-07-13). The acetate-Ra complexation constant was derived from the extrapolation of the complexation constants for the other acetate-alkaline earth metals. 
The sorption onto ferrihydrite was modeled by using the surface complexation modeling routine within PHREEQC with the sorption constants and the site density from Dzombak and Morel [71]. The carbonate surface complexation constants onto ferrihydrite originated from the Minteq database, the uranyl-carbonate surface complexation constants from Mahoney et al. [74], the cesium sorption constant from Gossuin et al. [75] and the Ra surface complexation constants and specific surface area from Sajih et al. [44]. The sorption on montmorillonite used a multi-site ion exchange model according to the Gaines-Thomas convention. The exchange constants for montmorillonite originated from Robin et al. [42] and the Ra exchange constants are the constants on beidellite from Robin et al., which are applicable to montmorillonite [76]. The sorption of Ba on montmorillonite was assumed to be equivalent to the sorption of Ra. Supplementary Materials Section 3.2 describes the calculation of the $\mathrm{Cs}$ and $\mathrm{U}$ sorption constants [77-79].

The model for a $(\mathrm{Ba}, \mathrm{Ra}) \mathrm{SO}_{4}$ solid solution was implemented using partition parameters from Curti et al. [80]. This solid solution allowed the incorporation of ${ }^{226} \mathrm{Ra}$ into the structure of barite. The ${ }^{226}$ Ra equilibrium in the solid solution is described by a distribution coefficient $\mathrm{D}$ (see Equation (1)) at thermodynamic equilibrium [46,81].

$$
\mathrm{D}=\frac{\left(\frac{\mathrm{Ra}}{\mathrm{Ba}}\right) \text { solid }}{\left(\frac{\mathrm{Ra}}{\mathrm{Ba}}\right) \text { solution }}=\frac{\lambda \mathrm{BaSO}_{4} \cdot \gamma \mathrm{Ra} \cdot \mathrm{K}_{\mathrm{s}}^{0}\left(\mathrm{BaSO}_{4}\right)}{\lambda \mathrm{RaSO}_{4} \cdot \gamma \mathrm{Ba} \cdot \mathrm{K}_{\mathrm{s}}^{0}\left(\mathrm{RaSO}_{4}\right)} .
$$

The term $\gamma$ is the ion activity coefficient and $\lambda$ is the activity coefficient of the phases in the solid solution. $\mathrm{K}_{\mathrm{S}}^{0}\left(\mathrm{BaSO}_{4}\right)$ and $\mathrm{K}_{\mathrm{S}}^{0}\left(\mathrm{RaSO}_{4}\right)$ are the solubility constants of $\mathrm{BaSO}_{4}$ and $\mathrm{RaSO}_{4}$ respectively. In a dilute regular solid solution, application of Henry's law to the trace end-member $\left(\mathrm{RaSO}_{4}\right)$ and Raoult's law to the major end-member $\left(\mathrm{BaSO}_{4}\right)$ leads to the following simplification: $\operatorname{Ln}\left(\lambda \mathrm{BaSO}_{4}\right)=0$ and $\operatorname{Ln}\left(\lambda \mathrm{RaSO}_{4}\right)=\mathrm{a}_{0}$, where $\mathrm{a}_{0}$ is the Guggenheim parameter indicating the deviation from an ideal solid solution. The implementation of the solid-solution model here used an $\mathrm{a}_{0}$ value of 1.5 , the value found by Curti et al., Zhang et al. and Brandt et al. at $23 \pm 2{ }^{\circ} \mathrm{C}[51,80,82]$.

Table S1 in Supplementary Materials Section 3.1 summarizes the modeling parameters used to describe the sorption and the formation of the solid solution. The calculations were performed at $25^{\circ} \mathrm{C}$ with coherent thermodynamic constants [73].

\subsection{Model Construction for the Sequential Extractions on Bois Noirs Limouzat Mill Tailing Samples}

\subsubsection{Mineral Quantities}

The quantity of montmorillonite was determined using the total $\mathrm{Al}$ content of the samples measured by chemical analysis of the tailings. The Al content of a sample does not only reflect the montmorillonite content but also the presence of other phyllosilicates and feldspars. These minerals have lower sorption capacities than montmorillonite. However, in the clayey silty samples, Al was considered to be a good approximation, bearing in mind that the quantity of montmorillonite is then overstated.

The model did not include the chemical composition of montmorillonite, as it was assumed that montmorillonite did not react during sequential extraction. The calculated quantity allowed the determination of the number of sorption sites according to the site concentrations from Tertre [68].

Two models were constructed based on how the quantities of gypsum, barite and ferrihydrite were derived from:

1. For the optimum model: from the quantities of total aqueous $\mathrm{SO}_{4}$, total aqueous $\mathrm{Ba}$ and total aqueous Fe respectively that were extracted during the sequential extractions. This "optimum model" will be discussed in the Results Section 3;

2. For the bulk model: only from the bulk analysis of the samples. The quantity of ferrihydrite was determined using the total Fe content of the bulk samples measured by chemical analysis, 
the quantity of gypsum from the total sulfur (S) content and the quantity of barite from the total Ba content. This "bulk model" will be discussed in the Discussion Section 4.1.

For both models, the quantity of barite is one order of magnitude lower than that of gypsum, its contribution to the $S$ content is deemed negligible in the calculation of the quantity of gypsum. The mineral assemblages appear in Table 3. The assumptions on which the mineral quantities are based and the sensitivity of the model to the mineral quantities will be discussed in Section 4.1.

Table 3. Mineral quantities in the mineral assemblages implemented in the optimum model, and the model derived from the bulk mineralogy.

\begin{tabular}{ccccccccc}
\hline \multirow{2}{*}{ Sample } & \multicolumn{2}{c}{ Gypsum (mol/g) } & \multicolumn{2}{c}{ Ferrihydrite (mol/g) } & \multicolumn{2}{c}{ Barite (mol/g) } & \multicolumn{2}{c}{ Montmorillonite (g/g) } \\
& $\begin{array}{c}\text { Optimum } \\
\text { Model }\end{array}$ & $\begin{array}{c}\text { Bulk } \\
\text { Model }\end{array}$ & $\begin{array}{c}\text { Optimum } \\
\text { Model }\end{array}$ & $\begin{array}{c}\text { Bulk } \\
\text { Model }\end{array}$ & $\begin{array}{c}\text { Optimum } \\
\text { Model }\end{array}$ & $\begin{array}{c}\text { BULK } \\
\text { MODEL }\end{array}$ & Both Models \\
\hline C1P3B & $2.8 \times 10^{-4}$ & $1.69 \times 10^{-4}$ & $2.5 \times 10^{-5}$ & $3.6 \times 10^{-4}$ & $1.1 \times 10^{-5}$ & $5.1 \times 10^{-6}$ & 0.37 \\
C1P5H & $1.4 \times 10^{-4}$ & $2.35 \times 10^{-4}$ & $4.0 \times 10^{-5}$ & $4.1 \times 10^{-4}$ & $2.9 \times 10^{-6}$ & $2.1 \times 10^{-6}$ & 0.43 \\
C1P11B & $5.8 \times 10^{-5}$ & $8.1 \times 10^{-5}$ & $2.0 \times 10^{-5}$ & $3.6 \times 10^{-4}$ & $3.9 \times 10^{-6}$ & $2.1 \times 10^{-6}$ & 0.47 \\
\hline
\end{tabular}

\subsubsection{Building the Initial State of the Model for the Tailing Samples}

The mineral assemblage of the tailings was considered to be in equilibrium with the pore water. Knowledge of the composition of the interstitial solution is necessary to implement the sorption and mineral equilibria of the modeled tailing samples before undertaking the sequential extraction procedure: it allows the initial state to accurately model the cation distribution on the sorption sites of the material that will govern the sorption equilibrium of the radionuclides in trace concentrations. The pore water analysis was chosen from a previous study on the Bois Noirs Limouzat tailings [83]. The pore water analysis labelled S4 in this study was selected for its close-to-equilibria electrical balance and its analogy to a clayey silty sample: it was in equilibrium with a solid sample with high ${ }^{226} \mathrm{Ra}$ and U solid concentrations $\left(103 \mathrm{~Bq} / \mathrm{g}\right.$ and $735 \mathrm{ppm}-3.09 \times 10^{-3} \mathrm{~mol} / \mathrm{kg}$, respectively). The chemistry of the pore water (see Supplementary Materials Section 4 Table S2), confirmed the solubility equilibrium of the minerals considered.

The $U$ concentration in the pore water solution was chosen from the mean value of the concentrations measured by the IPSN (now Institut de Radioprotection et de Sûreté Nucléaire IRSN) study [83] by squeezing: $1 \times 10^{-5} \mathrm{~mol} / \mathrm{L}$. It was checked that the U value fixed on the solid assemblage was close to the quantity of $U$ extracted during the sequential extractions. It was initially assumed that all the extractable ${ }^{226} \mathrm{Ra}$ is bound in the $(\mathrm{Ba}, \mathrm{Ra}) \mathrm{SO}_{4}$ solid solution. This assumption will be discussed below. The ${ }^{226} \mathrm{Ra}$ extracted during the sequential extractions from each sample was inserted into the $(\mathrm{Ba}, \mathrm{Ra}) \mathrm{SO}_{4}$ solid-solution, which then equilibrated with the other phases in the model to reach the initial equilibrium. Only the extractable $U$ and ${ }^{226} R$ a were considered. Proportions of $U$ and ${ }^{226} \mathrm{Ra}$ that are not extracted during the sequential extractions were assumed to be in refractory minerals and was considered inactive and immobile.

\subsubsection{Modeling the Extraction Steps}

The extraction steps, the reactants used in each step and their quantities are shown in Table 1. The liquid:solid ratio (defined as volume of reagent solution in $\mathrm{mL}$ to mass of solid sample in $\mathrm{g}$ ) used in the sequential extractions is $25 \mathrm{~mL} / \mathrm{g}$. Five washes with the same reactant during $2-5 \mathrm{~h}$ reaction time each were performed experimentally [22], and all five washes were modeled but the results presented here only gather the composition of the first two washes as in the experimental extractions. This choice for the experimental extractions was justified by the observation that these first washes accounted for most of the $U$ extracted. This observation did not consider ${ }^{226} \mathrm{Ra}$. Depending on the retention mechanism for ${ }^{226} \mathrm{Ra}$, its behavior might be different. If ${ }^{226} \mathrm{Ra}$ is bound by a solid solution, its leachability will not drastically change with the washes as long as the solid-solution is not completely depleted of ${ }^{226} \mathrm{Ra}$. 
The purpose of sequential extractions requires sizing, which aims to guarantee equilibrium and complete dissolution of the targeted fractions. It was, therefore, considered that thermodynamic equilibrium is reached at the end of each wash in agreement with our modeling hypotheses.

\subsection{Test Model for the Mineral Reactivity Towards Each of the Reactants}

First, a test model was performed to better understand the considered mineral reactivity towards each of the reactants used, and to identify possible constraints on the use of this protocol, especially in the search for the ultra-trace ${ }^{226} \mathrm{Ra}$.

The test model used the C1P3B sample considering the equivalent to a $1.6 \mathrm{~g}$ sample built with the "optimum model" construction (refer to Table 3). The ${ }^{226} \mathrm{Ra}$ activity of the sample was fixed at $50 \mathrm{~Bq} / \mathrm{g}$, the ${ }^{226}$ Ra being only bound by one of three possible phases: montmorillonite, ferrihydrite or barite. The objective was to survey how each of the possible binding phases reacts with the reactants used. Five washes with $40 \mathrm{~mL}$ of one of the reactants are simulated on this assemblage. The liquid:solid ratio $(25 \mathrm{~mL} / \mathrm{g})$ is the same as the experimental ratio and is close to the standard ratio for sequential extractions, as seen previously (see Figure $\mathrm{S1}$ ). The results depend greatly on the liquid:solid ratio used which fixes the solubility of the minerals: it must ensure a complete dissolution of the targeted phase by the corresponding extraction step. Because of the small amount of solid being considered, compared to the quantity of reactant, it is expected that all minerals should undergo partial to major dissolution.

The aqueous forms of sulfur were forced to stay in their $\mathrm{S}(\mathrm{VI})$ forms, preventing their reduction during the hydroxylamine hydrochloride + hydrochloric acid reaction. This should not affect the final results as sulfates were not involved during this step of the sequential extractions. In order to fix $50 \mathrm{~Bq} / \mathrm{g}{ }^{226} \mathrm{Ra}$ on the minerals, the aqueous concentration of ${ }^{226} \mathrm{Ra}$ in the initial equilibrium solution was modified. It was set at $1.1 \mathrm{~Bq} / \mathrm{L}$ to fix $50 \mathrm{~Bq} / \mathrm{g}{ }^{226} \mathrm{Ra}$ on the barite, $2.0 \times 10^{3} \mathrm{~Bq} / \mathrm{L}$ for montmorillonite and $2.5 \times 10^{5} \mathrm{~Bq} / \mathrm{L}$ for ferrihydrite. The in-situ solution measured in 1984 was between 1.4 and $22.6 \mathrm{~Bq} / \mathrm{L}[83]$.

\section{Results}

\subsection{The Reactivity of the Minerals with Each Reactant}

Because of the high liquid:solid ratio, at least partial dissolution of the barite in the extraction solutions is expected, although barite is usually considered insoluble $[37,55,58,84]$. The reactivity of barite with most of the reactants can be explained by its low quantity in the mineral assemblage compared to the volume of reactant used (6-18 $\mu$ moles barite in five consecutive washes of $40 \mathrm{~mL}$ of reactant), and by the relative abundance of montmorillonite (and ferrihydrite, but to a lesser extent) which can sorb the barium [85-87], and thus enhance the dissolution of the barite. Figure 1 illustrates the solubility of barite in deionized (DI) water with or without $1.475 \mathrm{~g}$ montmorillonite-consistent with sample C1P3B. Ba sorbs until the sulfate concentration is high enough to reach the saturation for barite with this small amount of Ba in solution. More details on the solubility of barite and ferrihydrite during the DI water extraction can be found in Supplementary Materials Section 5 (Figures S3 and S4 for barite and Figure S5 for ferrihydrite).

The results of the reactivity of the minerals with each reactant are plotted in Figure 2. The reactivity of the minerals is expressed by the remaining proportion of each mineral phase left after reaction with one reactant.

These results illustrate the selectivity effectiveness of each of the reactants (Figure 2a). Gypsum was dissolved by all the reagents and was thus appropriately targeted in the first stage of the extraction protocol (100\% of the gypsum was dissolved after the five washes with deionized water). Ferrihydrite was not dissolved by deionized water or $10^{-2} \mathrm{M} \mathrm{CsCl}$ but was completely dissolved by the other two reactants $(100 \%$ was dissolved after five washes with the $1 \mathrm{M}$ sodium acetate $+25 \%$ acetic acid and with $0.04 \mathrm{M}$ hydroxylamine hydrochloride $+\mathrm{HCl}$ ). Barite constituted the main issue: no extraction step specifically targeted barite, and yet it was affected by all the reactants. This lack of reactant selectivity 
compromises the efficiency of the extraction protocol. As previously mentioned, there is no protocol for efficiently extracting barite. This was not considered a problem since this extraction protocol was initially established for the study of $U$, which does not react with barite. Some studies using sequential extractions do test the reactivity of some pure phases, including barite, with the reactants [4,61], but not as a part of a mineral assemblage, which greatly influences the dissolution of barite.

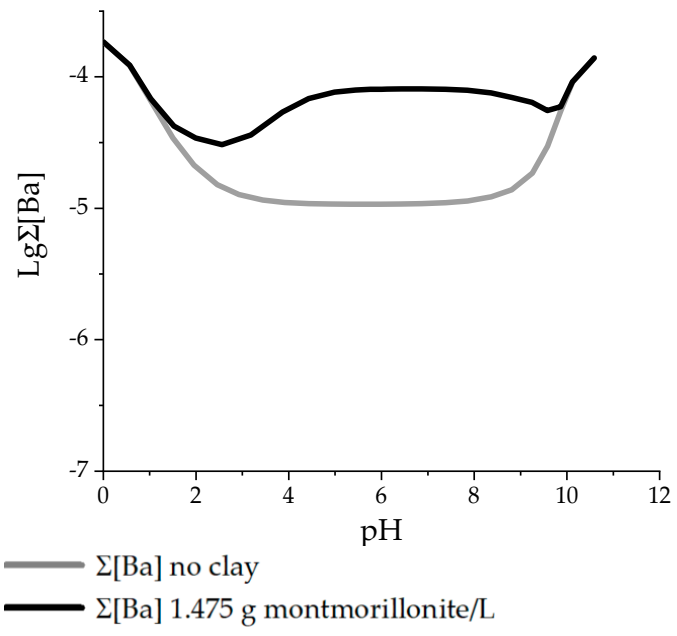

(a)

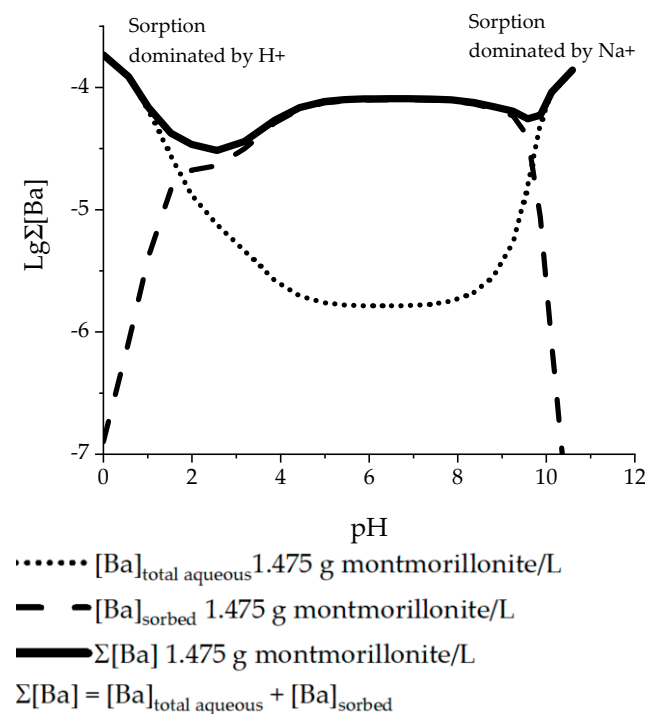

(b)

Figure 1. Solubility of barite in deionized (DI) water. (a) Concentration in mol/L of total Ba dissolved in a DI water solution in equilibrium with pure barite or with barite and $1.475 \mathrm{~g}$ montmorillonite per liter (i.e., $0.59 \mathrm{~g}$ per $40 \mathrm{~mL}$ ). The solution $\mathrm{pH}$ is adjusted with $\mathrm{HCl}$ or $\mathrm{NaOH}$. The clay minerals sites are initially put in equilibrium with a $1 \mathrm{M} \mathrm{CaCl}_{2}$ solution for the occupation of the clay minerals sorption sites to be close to the Ca-dominant case of this study. (b) Distribution of the total Ba dissolved between aqueous $\mathrm{Ba}$ in solution and sorbed $\mathrm{Ba}$ in $\mathrm{mol} / \mathrm{L}$ in a DI water solution in equilibrium with barite and $1.475 \mathrm{~g}$ montmorillonite per liter. The solubility of the barite is determined by $\Sigma[\mathrm{Ba}]=[\mathrm{Ba}]_{\text {total aqueous }}+[\mathrm{Ba}]_{\text {sorbed }}$.

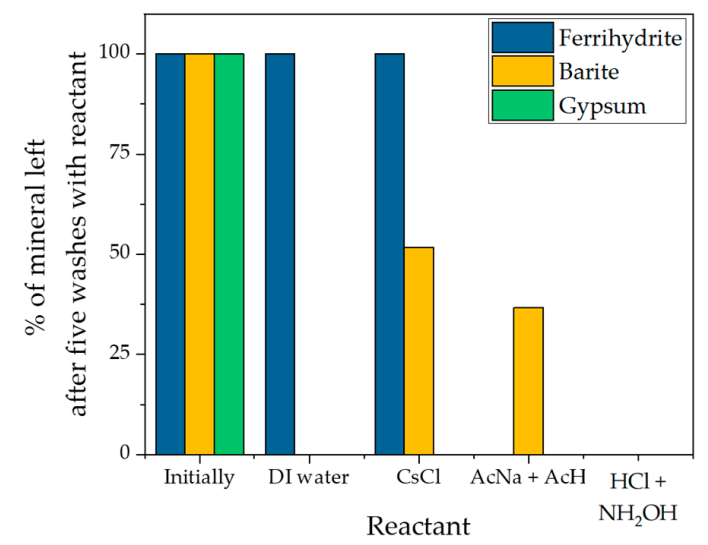

(a)

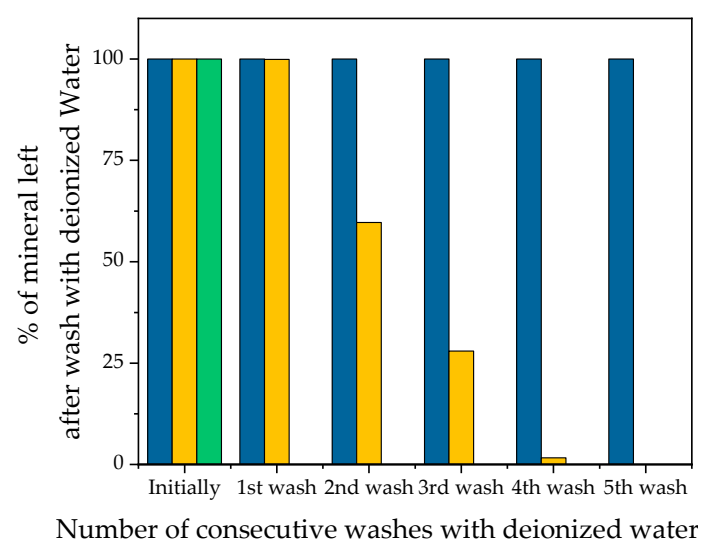

(b)

Figure 2. Selectivity effectiveness of each extraction reactant. Each reactant was tested individually on the mineral assemblage and not in consecutive steps. Percentage of minerals left, according to the model, after: (a) five washes of one of the reactants in the sequential extractions protocol; (b) each of the five washes with deionized water. Ac-Acetate. 
As shown in Figure 2b, gypsum was the first to dissolve in deionized water. The dissolution of gypsum limited the dissolution of barite because of the high amount of sulfate in the solution and the sorption of part of the Ca onto the clay minerals. The sulfate produced by the dissolution of the sulfate minerals was removed with the extraction solution between each wash, allowing for the dissolution of barite to start and continue throughout the washes: the total aqueous $\mathrm{Ba}$ and $\mathrm{SO}_{4}{ }^{2-}$ concentrations in solution were fixed at each wash by the solubility of the barite until its complete dissolution. Ba has a stronger affinity towards montmorillonite than other cations (refer to Table S1 in Supplementary Materials). As seen on Figure 1, the Ba did not remain in the deionized water solution but was sorbed onto the clay minerals at this step, allowing for barite to continue to dissolve. This could explain some of the Ba that was found in the exchangeable fraction during sequential extractions on samples containing both clay minerals and barite [3]: part of the Ba sorbed onto the clay minerals at the first step and then exchanged for Cs (or another cation, depending on the reactant used) on the clay mineral sorption sites. The low occurrence of barite in the tailing samples does not permit XRD identifications. During the experimental extractions, the remaining solid was observed by SEM after the deionized water extraction step. Before the extractions, barite was easily identified in the fine fraction of the residues (see Supplementary Materials Section 2). After the extraction, no barite was seen. These observations are in accordance with the complete dissolution of barite.

The test model now considers that $80 \mathrm{~Bq}$ of ${ }^{226} \mathrm{Ra}$ is initially bound in $1.6 \mathrm{~g}$ of the solid assemblage to montmorillonite, ferrihydrite or barite, respectively. The subsequent ${ }^{226}$ Ra extracted by each reactant can be seen in Figure 3.

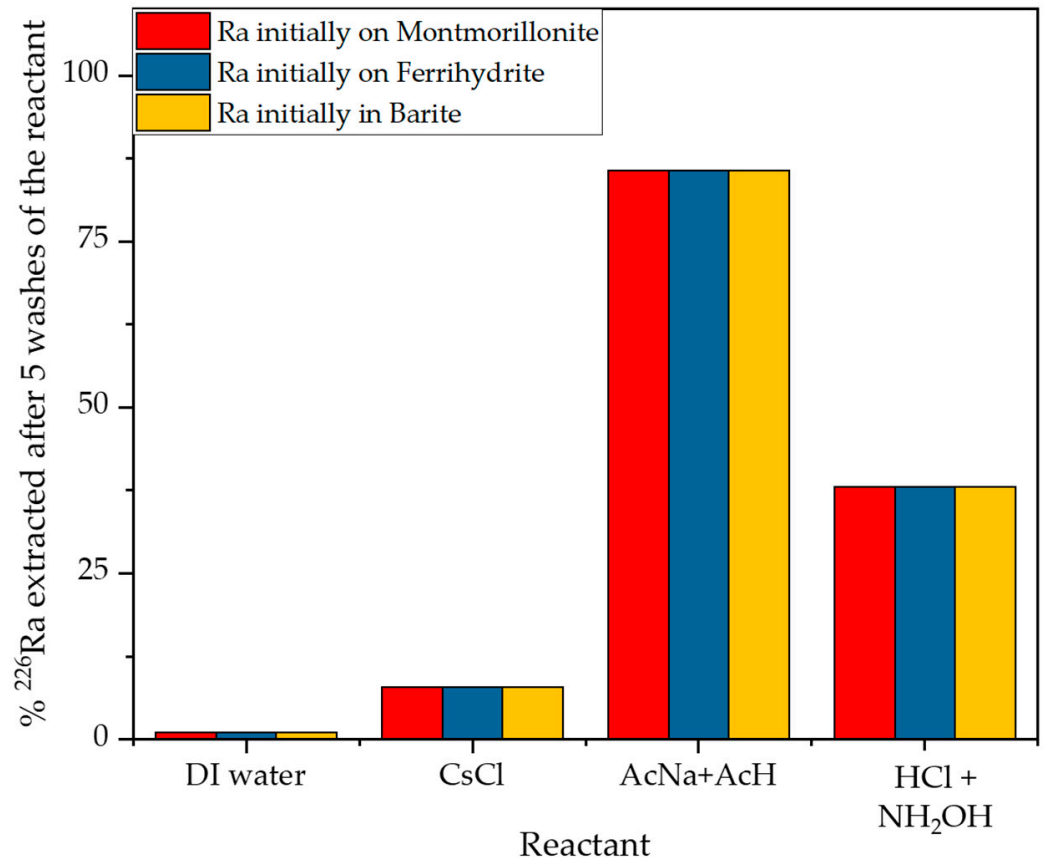

Figure 3. Percentage of ${ }^{226} \mathrm{Ra}$ extracted by five washes of one of the reactants depending on the mineral the ${ }^{226} \mathrm{Ra}$ is initially bound to.

The test model shows that regardless of the initial origin of the ${ }^{226} \mathrm{Ra}$, the extraction results with each of the reactants are the same. This is explained by the redistribution processes of ${ }^{226} \mathrm{Ra}$ between the minerals that happen during the reaction with the extraction reactants. Figure 4 shows the modeled distribution of ${ }^{226} \mathrm{Ra}$, before and after the reaction with deionized water. Because of the small quantity of barite, combined with the presence of montmorillonite, the deionized water dissolves the barite and the ${ }^{226} \mathrm{Ra}$ is totally redistributed onto the montmorillonite and ferrihydrite. Montmorillonite has a greater affinity for $\mathrm{Ra}$ and a larger sorption capability due to its greater abundance compared with ferrihydrite. ${ }^{226} \mathrm{Ra}$ therefore sorbs preferentially onto montmorillonite. The ${ }^{226} \mathrm{Ra}$ will reach a new 
equilibrium during the first extraction step, this equilibrium depending on the remaining mineralogy of the solid and not on the origin of ${ }^{226} \mathrm{Ra}$. This illustrates well the redistribution processes which may happen during extractions and which can lead to misinterpretations.

(a) Initial distribution of ${ }^{226} \mathrm{Ra}$

(b) ${ }^{226} \mathrm{Ra}$ distribution after five deionized water washes

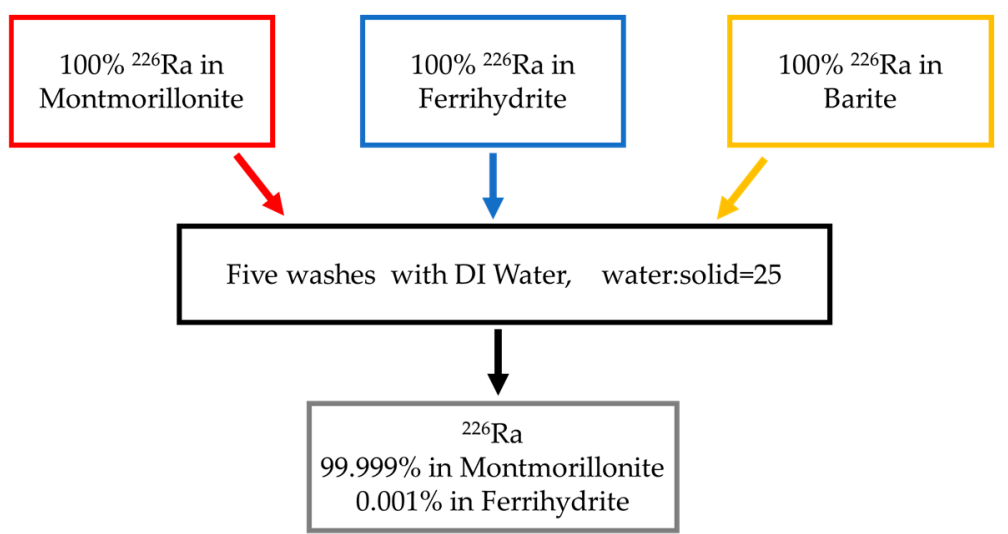

Figure 4. Illustration of the redistribution of the ${ }^{226} \mathrm{Ra}$ after five washes with deionized water. ${ }^{226} \mathrm{Ra}$ distribution in the mineral assemblage (a) before reaction, the ${ }^{226} \mathrm{Ra}$ was initially considered to be on montmorillonite or ferrihydrite or barite, respectively; (b) after reaction with five washes of deionized water (water:solid ratio of 25). The result is the same for the three initial scenarios.

Figure 3 shows that, regardless of the initial ${ }^{226}$ Ra-binding mineral, the $10^{-2} \mathrm{M} \mathrm{CsCl}$ reactant only extracted around $10 \%$ of the ${ }^{226} \mathrm{Ra}$. The Cs sorption affinity on the sorption site of montmorillonite being weaker than for ${ }^{226} \mathrm{Ra}$, this concentration of $10^{-2} \mathrm{M} \mathrm{Cs}$ is not sufficient to desorb the Ra from the clay minerals. On the other hand, the acetate extraction, designed to target weakly-crystallized iron oxides, released the majority (85\%) of the ${ }^{226}$ Ra regardless of whether it was initially bound with barite, ferrihydrite or montmorillonite. The $25 \%$ acetic acid, $1 \mathrm{M}$ sodium acetate reactant dissolved both ferrihydrite and most of the barite $(65 \%)$, and the concentration of cations during this extraction step, $1 \mathrm{M} \mathrm{Na}^{+}$and $10^{-4} \mathrm{M} \mathrm{H}^{+}$, was sufficiently high to desorb most cations from the clay minerals by exchanging those cations with $\mathrm{Na}^{+}$and $\mathrm{H}^{+}$on the sorption sites. Part of the ${ }^{226} \mathrm{Ra}$ remained trapped in the $(\mathrm{Ba}, \mathrm{Ra}) \mathrm{SO}_{4}$ solid solution (about $15 \%$ of extractable ${ }^{226} \mathrm{Ra}$ here).

Now the sequential extractions are modelled to estimate the influence of non-selectivity and redistribution processes on the results of the experimental sequential extractions.

\subsection{Understanding the Sequential Extraction of Tailing Samples through Modeling}

The model considered the sequential extraction protocol being applied to three clayey silty-type samples. The results discussed here concern only the C1P3B sample. The results for samples C1P5H and $\mathrm{C} 1 \mathrm{P} 11 \mathrm{~B}$, which are quite similar, are presented in Supplementary Materials Section 6.1 in Figures S6 and S7, respectively.

The "optimum model" is the sequential extraction model being discussed here. The "bulk model" in this figure will be discussed in Section 4.1. As mentioned earlier, this "optimum" model was built from calculations based on assumed equilibrium solubility and sorption using existing thermodynamic data and using apparent mineral quantities estimated from the mineral-specific leaching steps and bulk mineralogy for the clay content. The model extractions are in good agreement with the experimental sequential extractions, from major to ultra-trace elements, as can be seen in Figure 5 showing the quantities of selected major $\left(\mathrm{Ca}, \mathrm{SO}_{4}{ }^{2-}\right)$, accessory $(\mathrm{Fe}, \mathrm{Ba})$, trace $(\mathrm{U})$ and ultra-trace $\left({ }^{226} \mathrm{Ra}\right)$ elements extracted during the sequential extractions. The maximum deviation between the experimental and modeled data for the C1P3B sample is the Ba extracted at the acetate extraction step: $6 \times 10^{-7} \mathrm{~mol} / \mathrm{g}$ was measured while $2 \times 10^{-6} \mathrm{~mol} / \mathrm{g}$ was modeled. 

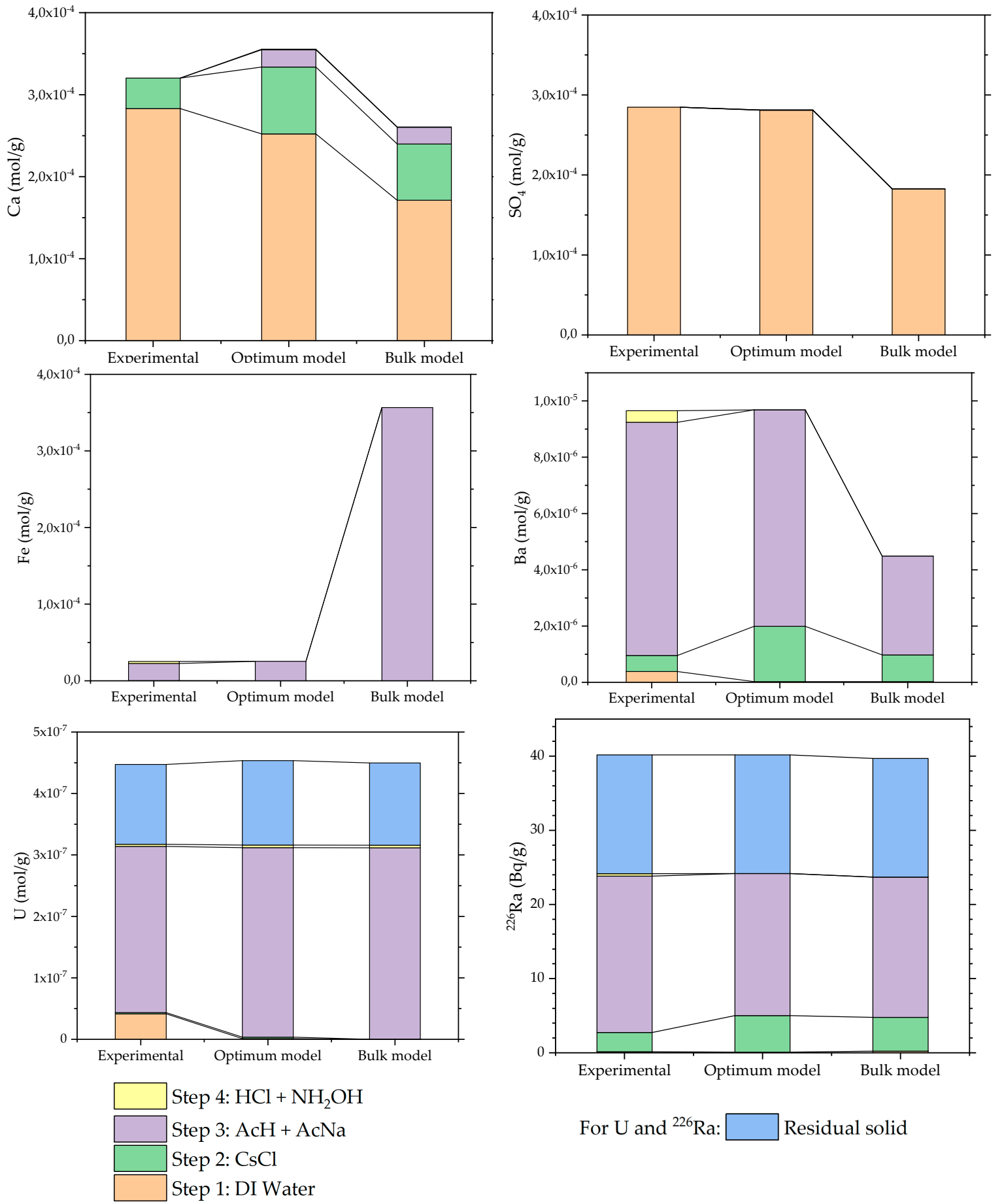

Figure 5. Extraction results for experimental data extractions (Chautard et al. [22]) and this study's model optimized ("optimum model") and built from bulk data ("bulk model") for $\mathrm{Ca}, \mathrm{SO}_{4}, \mathrm{Fe}, \mathrm{Ba}, \mathrm{U}$ and ${ }^{226}$ Ra per $g$ of solid for the C1P3B sample.

\subsubsection{Behavior of the Major Elements}

Among the major elements, two categories are distinguishable: the first type represents the major elements whose chemistry is governed by the dissolution of sulfate minerals, and includes $\mathrm{SO}_{4}, \mathrm{Ca}$ and $\mathrm{Ba}$; the second consists of Fe whose behavior during the extractions is governed by the reactivity of the iron oxyhydroxides. The model also considered the other major elements but those were either 
used as reactants $(\mathrm{Na}$ and $\mathrm{Cl}$ ) or in small quantities and are not relevant to the behavior of the minerals in the model ( $\mathrm{Mg}$ and $\mathrm{K})$.

$\mathrm{Ca}, \mathrm{SO}_{4}^{2-}, \mathrm{Ba}$

The main sources of aqueous $\mathrm{Ca}$, aqueous $\mathrm{SO}_{4}$ and aqueous $\mathrm{Ba}$ are gypsum and barite. As seen previously, both were dissolved by deionized water during the first extraction step. $\mathrm{SO}_{4}$ sorption is limited [71], inducing its total extraction during the first extraction step. The clay sorption sites were initially occupied mostly by $\mathrm{Ca}$ but also by $\mathrm{Mg}, \mathrm{Na}$ and $\mathrm{K}$ which are major cations in the pore water solution. Part of the $\mathrm{Ca}$ and most of the Ba from the dissolution of the sulfate minerals were sorbed onto the clay minerals, especially as these were in a less concentrated solution than the tailings pore water and could desorb part of the $\mathrm{Na}$ and $\mathrm{Mg}$ which had been initially sorbed. This part of the $\mathrm{Ca}$ and $\mathrm{Ba}$ was then extracted during the steps that desorbed those elements from the clay minerals, i.e., the $10^{-2} \mathrm{M} \mathrm{CsCl}$ extraction step to some extent, and also the acetate extraction step. For all samples, the $10^{-2} \mathrm{M} \mathrm{CsCl}$ extraction step extracted about $20 \%$ of the $\mathrm{Ba}$, and the acetate extraction step, $80 \%$; for Ca it was about $30 \%$ and $10 \%$.

$\mathrm{Fe}$

The main source of iron in the model is ferrihydrite. It was not affected by the first two extraction steps but completely dissolved during the acetate extraction which extracted $100 \%$ of the leachable Fe.

\subsubsection{Trace and Ultra-Trace Elements Behavior and Distribution: $U$ and ${ }^{226} \mathrm{Ra}$}

The modeled extraction of $U$ and ${ }^{226} \mathrm{Ra}$ is close to the experimental results for all three samples (Figure 5 and Supplementary Materials Section 6.1): the acetate extraction step aiming for iron oxides released $98 \%$ of the extractable $U$ and $80 \%$ of the extractable ${ }^{226} \mathrm{Ra}$. However, the model also provides an indication on the initial $U$ and ${ }^{226} \mathrm{Ra}$ distribution equilibrium in the mineral assemblage before extractions. This distribution is presented in Figure 6 as well as the distribution of $U$ and ${ }^{226}$ Ra derived from a direct interpretation of the sequential extraction results, which directly associates the elements extracted at each step to the targeted fraction. The distributions for the samples C1P5H and C1P11B are shown in Supplementary Materials Section 6.2 in Figures S8 and S9, respectively.

$\mathrm{U}$

According to the sequential extraction results, the extractable $U$ is mostly bound to the ferric oxyhydroxides, and a small part $(<10 \%)$ to the labile fraction (C1P3B sample, Figure 6$)$ and to the clay minerals (C1P11B sample, Figure S9). The initial state model agrees with this general distribution but attributes an even larger part to the contribution of ferrihydrite binding to almost all the extractable $U$ (clay minerals are accountable for less than $1 \%$ of the $\mathrm{U}$ ). It seems that during the deionized water extraction, part of the $\mathrm{U}$ sorbed on ferrihydrite was replaced by protons (the $\mathrm{pH}$ of the deionized water is lower than the 8.1 of the pore water). The desorbed $U$ remained in the solution or sorbed on the clay minerals: the first step extracted about $1 \%$ of the U. During the first extraction step, using deionized water, the clay minerals were in a solution that was much less concentrated than the pore water (see Supplementary Materials Table S2): at the first extraction step the clay minerals released some $\mathrm{Mg}$, $\mathrm{Na}, \mathrm{K}$, and could sorb the part of $\mathrm{U}$ released by the ferrihydrite. Then, the extraction step using $10^{-2}$ $\mathrm{M} \mathrm{CsCl}$ reactant partially released this part of the U (refer to Table S1 in Supplementary Materials). The C1P11B sample is richer in Al, and therefore probably also in clay minerals, than the other two samples (see Supplementary Materials Section 4). The clay minerals sorbed more U at the deionized water extraction step and released more $\mathrm{U}$ at the $\mathrm{CsCl}$ step: this step released $4 \%$ of the extractable $\mathrm{U}$ for the $\mathrm{C} 1 \mathrm{P} 11 \mathrm{~B}$ sample against $1 \%$ for the two other samples. 


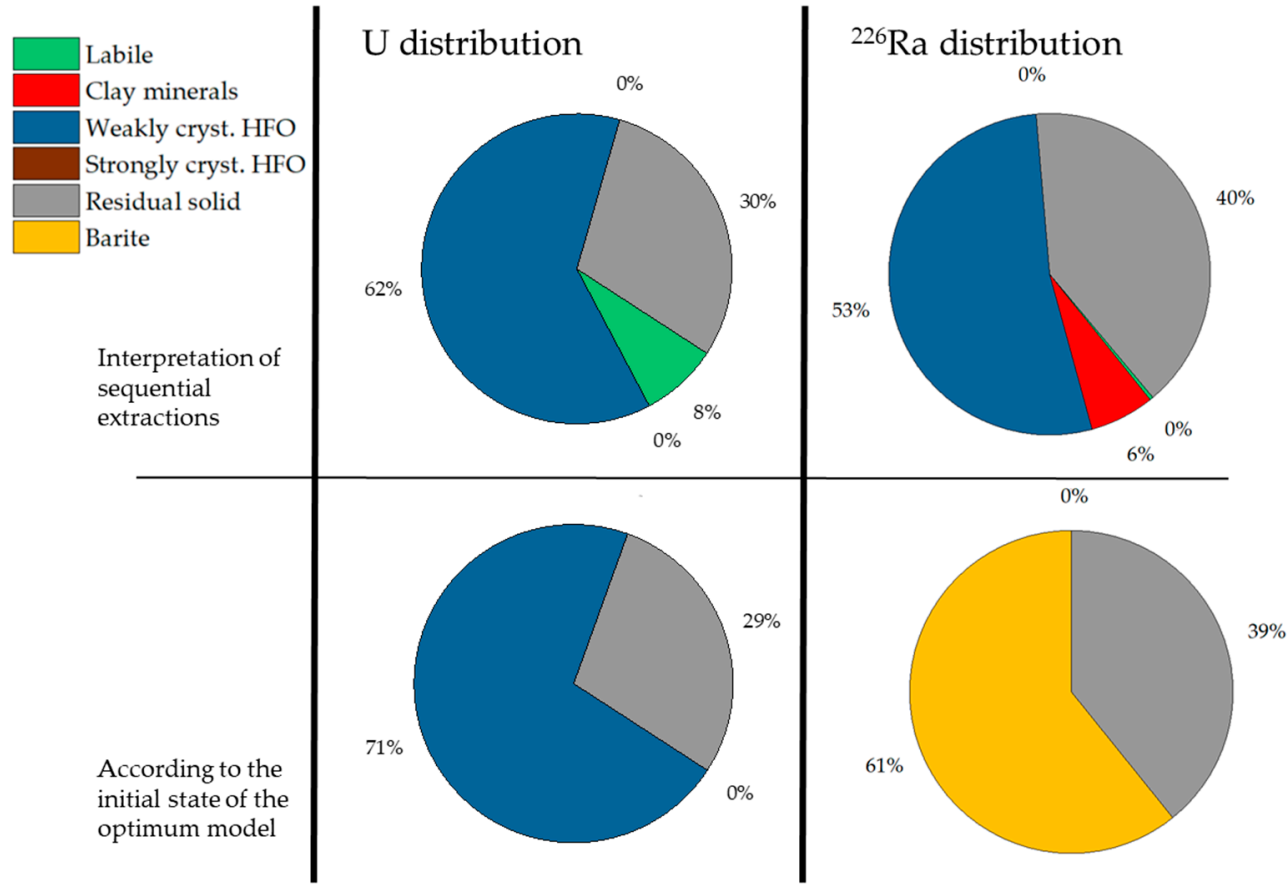

Figure 6. $\mathrm{U}$ and ${ }^{226} \mathrm{Ra}$ initial distribution in the C1P3B sample according to the direct interpretation of the sequential extraction results (the concentrations in the leachates) and the initial state model (the thermodynamic equilibrium between the minerals present and the pore water) (cryst.—crystallized, HFO-hydrous ferric oxyhydroxides).

The initial distribution of $U$ as described in the model is in good agreement with the distribution obtained from the direct interpretation of the experimental results by Chautard et al. [22]. This sequential extraction protocol is suitable for the study of $U$ in the tailing samples, as it was designed to specifically target the minerals identified as U-binding phases. ${ }^{226} \mathrm{Ra}$ was also monitored, knowing that the binding phases are not the same.

226. $\mathrm{Ra}$

Direct interpretation of the sequential extractions indicates that the extractable part of ${ }^{226} \mathrm{Ra}$ is bound to the ferrihydrite, with a small portion on the clay minerals $\left(6 \%\right.$ of ${ }^{226} \mathrm{Ra}$ on clay minerals for the C1P3B sample). According to the model, barite is the major source of extractable ${ }^{226} \mathrm{Ra}$.

In Section 2.4, it was mentioned that the ${ }^{226}$ Ra concentration of the solution initially in equilibrium with the sample should be much higher when the ${ }^{226} \mathrm{Ra}$ is bound to montmorillonite or ferrihydrite. The initial state of the same samples was modeled without considering the possibility of a (Ba, $\mathrm{Ra}) \mathrm{SO}_{4}$ solid solution. According to the ${ }^{226} \mathrm{Ra}$ concentration measured in pore water $(1.5 \mathrm{~Bq} / \mathrm{L})$ and used in the model presented here, the ${ }^{226}$ Ra sorbed on clay minerals and ferrihydrite only accounted for less than $1.5 \%$ of the extractable ${ }^{226} \mathrm{Ra}$ of the samples. It should be stressed that the model did reach these results, albeit by maximizing the quantity of clays. Thus, barite is necessarily a major source of ${ }^{226} \mathrm{Ra}$ in the samples considered, justifying the assumption of Section 2.3.2.

However, as this mineral was not considered during the extraction protocol, it does not appear on the experimental results interpretation. The ${ }^{226} \mathrm{Ra}$ extracted and attributed to other minerals is the result of partial to complete dissolution of the barite and redistribution of Ba and ${ }^{226} \mathrm{Ra}$. Barite was completely dissolved during the deionized water extraction step because of its small quantity and the ability of clay minerals to sorb Ba (Figure 1). The ${ }^{226} \mathrm{Ra}$ that was initially in (Ba,Ra) $\mathrm{SO}_{4}$ solid solution was mostly sorbed on the clay minerals. Because ${ }^{226}$ Ra sorption on montmorillonite is strong, the $10^{-2} \mathrm{M} \mathrm{CsCl}$ extraction was not sufficient to desorb this ${ }^{226} \mathrm{Ra}$ (Figure 3). The protocol aimed to desorb $\mathrm{U}$, which works using Cs. However, ${ }^{226} \mathrm{Ra}$ does not have the same sorption constants: 
Ra has more affinity towards montmorillonite than Cs (refer to Table S1 in Supplementary Materials). Ra remained sorbed on the clay minerals until the $25 \%$ acetic acid/1M sodium acetate step brought a concentration of cations sufficient to desorb all other cations from the clay minerals, including ${ }^{226} \mathrm{Ra}$. Thus, all the ${ }^{226} \mathrm{Ra}$ that was initially in solid solution with the barite was extracted during the acetate extraction that aimed initially to target the weakly-crystallized iron oxyhydroxide compartment.

The sequential extraction modeled results are similar for all three samples: the extraction results are accurately reproduced but ${ }^{226} \mathrm{Ra}$ is bound to the barite. The extraction protocol is not well designed for Ra because it is an ultra-trace element, its behavior is influenced by different binding phases (including barite) and its high sorption affinities.

\section{Discussion}

\subsection{Building the Model with Less Data: A Sensitivity Study}

The model presented in Section 4 refers partially to data from sequential extractions and therefore requires that experimental part beforehand. However, a comparable model can be constructed without sequential extraction results.

The same model was applied to the sequential extractions on the C1P3B, C1P5H and C1P11B samples, but by constructing the mineralogical assemblage modeled with mineral quantities derived only from the bulk analysis of the samples. Only the ${ }^{226} \mathrm{Ra}$ and $\mathrm{U}$ quantities came from the total quantity of ${ }^{226} \mathrm{Ra}$ and $\mathrm{U}$ extracted and measured in the residual solid after the extractions. This forms the "bulk model", described in Section 2.3.1. The comparison of:

1. the experimental results with

2. the results obtained from the sequential extraction model presented previously - the "optimum model" built upon the mineral quantities derived from experimental leaching data-and with

3. the results of this modeling of sequential extractions-the "bulk model" can be found for sample C1P3B in Figure 5, and for samples C1P5H and C1P11B in Supplementary Materials Section 6.1.

Compared to the experimental results, the construction of the bulk model provided less accurate results than the optimum model for the total aqueous concentrations of $\mathrm{Ca}, \mathrm{Fe}, \mathrm{Ba}, \mathrm{SO}_{4}$ as their total quantity may be affected by a skew in the subsampling. This model is built with less accurate data concerning the sample and thus provides results of poorer quality. However, despite changes in total amount of elements available, the behavior of the major elements remained similar to the experimental results.

It should be highlighted that the results from both models for $U$ and ${ }^{226} \mathrm{Ra}$ ("optimum" and "bulk") were close to the experimental results, because the sorption sites and the solid-solution's capacity to trap $U$ and ${ }^{226} \mathrm{Ra}$ are in excess in both models. $U$ and ${ }^{226} \mathrm{Ra}$ retention do not vary much when small adjustments of the mineralogy are performed. The sensitivity of the model to the quantities of the minerals is relatively low. The results of the sequential extractions on $\mathrm{U},{ }^{226} \mathrm{Ra}$, and other trace elements could be modeled only from bulk analyses-perhaps with pore water data-and the quantities of extractable $\mathrm{U}$ and ${ }^{226} \mathrm{Ra}$. The latter are determined experimentally by a non-complete digestion (1 M acetate reactant for example). In this study, it leads to a better understanding of the interactions during sequential extractions. For many trace elements, this kind of modeling could avoid the need for the tedious procedure of chemical extractions and help with an immediately improved understanding of the host phases of the extractable fraction.

\subsection{Field Application: A Different Interpretation on the Origin of Extractable ${ }^{226}$ Ra in Tailing Samples}

This study highlights the importance of barite as the initial ${ }^{226}$ Ra-binding mineral in these tailing samples. This is consistent with the precipitation of barite due to the addition of large quantities of sulfate during the mill process. 
The model only considers the total extractable fractions of $U$ and ${ }^{226} \mathrm{Ra}$ because they were deemed the most important parts in relation to environmental issues. The experimental study determined that a majority of ${ }^{226} \mathrm{Ra}$ and $30 \%$ of $\mathrm{U}$ are not extractable, i.e., not mobile in the environment. These non-mobile fractions of $U$ and $R a$ are most likely bound to $U$-oxides, uranyl-phosphates and aluminum phosphate-sulfates which the extractants used do not solubilize. The extraction procedure could have dissolved a minute proportion of the phosphates which is considered to be negligible. The extractable part of $\mathrm{U}$ and ${ }^{226} \mathrm{Ra}$, was identified by the experimental study as being bound to iron oxyhydroxides. This phase is quite stable in the tailings environment but is vulnerable to changes of $\mathrm{pH}$ and redox, which could lead to the release of the sorbed ${ }^{226} \mathrm{Ra}$. However, the current numerical study concludes that extractable ${ }^{226} \mathrm{Ra}$ would be in the form of a $(\mathrm{Ra}, \mathrm{Ba}) \mathrm{SO}_{4}$ solid-solution. At the scale of the tailing system, this statement changes the conclusions for the long-term behavior of the extractable part of ${ }^{226} \mathrm{Ra}$. Barite is stable in the calcium sulfate-rich pore waters of the tailings. The solubility equilibrium of the solid solution governs the Ra concentration, as long as the water renewal does not extract all the ${ }^{226} \mathrm{Ra}$ bound to the barite in the tailings. The pore water ${ }^{226} \mathrm{Ra}$ concentration at equilibrium with the mineral assemblage is around 0.5 to $1 \mathrm{~Bq} / \mathrm{L}$, close to the 1.4 to $22.6 \mathrm{~Bq} / \mathrm{L}$ measured in the pore water of the residues [83], but also to the $2.5 \mathrm{~Bq} / \mathrm{L}$ of the water-covered basin of the Bois Noirs Limouzat tailings facility [88]. This means that the whole Bois Noirs Limouzat tailing system is in equilibrium with a $(\mathrm{Ra}, \mathrm{Ba}) \mathrm{SO}_{4}$ solid-solution controlling all the extractable part of the ${ }^{226} \mathrm{Ra}$ in the tailings.

The ${ }^{226} \mathrm{Ra}$ activity of $2.5 \mathrm{~Bq} / \mathrm{L}$ in the basin water is consistent with a simple model of water in equilibrium with tailings containing barite in the form of a solid solution with the following composition $\mathrm{Ba}_{1}, \operatorname{Ra}\left(2.9 \times 10^{-7}\right)$. Calculations show that close to $20 \%$ of the total stock of ${ }^{226} \mathrm{Ra}$ in the tailings is retained in barite. Most of the remaining ${ }^{226} \mathrm{Ra}$ may be considered non-mobile. The long-term equilibrium and behavior of the tailing system when it comes to ${ }^{226} \mathrm{Ra}$ can be derived from the model of a homogeneous mineral assemblage containing barite in particular, but also clay minerals and iron oxyhydroxides. More detail on this calculation can be seen in Supplementary Materials Section 7. For future research, this study underlines one of the potential benefits of developing an extraction protocol for barite. The investigation of the physical separation of barite in a dry medium is possible. It is difficult to determine the binding phases of ${ }^{226} \mathrm{Ra}$ in rocks using sequential extractions. This lack of accuracy is of noteworthy importance for many industrial environmental issues. Direct observation of the spatial distribution of ${ }^{226} \mathrm{Ra}$ would bring more robust information on its mobility. Such localization techniques for ${ }^{226} \mathrm{Ra}$ on solid samples, for instance alpha autoradiography, have been used only in recent years and are yielding promising results [47,89-92].

\section{Conclusions}

The modeled results of the sequential extractions in this study are in good agreement with the experimental results for the elements of interest which are both the major and the trace elements ( $\mathrm{U}$ and ${ }^{226} \mathrm{Ra}$ ). This model could be applied to gain additional information on the behavior of the elements and minerals during the sequential extraction procedure. This sequential extraction protocol is well designed for the study of uranium in such samples, as the possible minerals which $U$ can be associated with, and their reactivity, were well identified. This is not entirely the case for ${ }^{226} \mathrm{Ra}$ : the modeled extraction results are close to the experimental results but the initial distribution of ${ }^{226} \mathrm{Ra}$ is different. The absence of a barite extraction step at the beginning of the extraction protocol leads to the redistribution among other minerals of the ${ }^{226} \mathrm{Ra}$ initially in the $(\mathrm{Ba}, \mathrm{Ra}) \mathrm{SO}_{4}$ solid solution. ${ }^{226} \mathrm{Ra}$ is particularly prone to redistribution as it is an ultra-trace element that can be bound to many different phases, all of which are in excess in terms of retention capacity for ${ }^{226} \mathrm{Ra}$ in the studied samples.

The current study establishes a rather simple model of tailing samples which nonetheless accurately reproduces the experimental results of sequential extractions conducted on these samples. The information provided by this model illustrate the problems regularly discussed concerning sequential extractions. This study particularly addresses the issues of the lack of operative protocols (no protocol exists to extract barite specifically), the non-selectivity of reagents in many cases and the 
redistribution of the elements of interest during the extraction procedure. Sequential extractions often target elements of interest in trace quantities, which are likely to be affected even by accessory minerals. However, few studies using sequential extractions consider the importance of accurate mineralogical characterization. Similarly, few sequential extraction procedures consider the importance of measuring a large set of trace elements (not only the targeted element) in the leachate at each step. Regardless of the sample or the extraction protocol, this study illustrates the importance of an extensive knowledge of the mineralogy of the sample, including accessory minerals, and of the chemical behavior of the element of interest. This study therefore concludes that the sequential extraction technique is to be used with extreme caution and is particularly inappropriate in the case of ${ }^{226} \mathrm{Ra}$, notably if the sample includes barite. Even a minute quantity of barite magnifies some of the limitations of sequential extractions, including the non-selectivity of reactants and the redistribution of ${ }^{226} \mathrm{Ra}$, which can lead to interpretative distortions or uncertainties. These conclusions can be applied to sequential extractions in other fields of study, for example, the study of trace radioelements in shales or phosphogypsum. Such modeling can also prevent the erroneous use of sequential extractions for many trace elements and help with an immediately improved understanding of the host phases of the extractable fraction of these elements.

Barite is the host phase of the available ${ }^{226} \mathrm{Ra}$ in the mill tailings that were studied. This may be in contradiction with other studies on similar tailings [4,18], which could therefore benefit from being reinterpreted with this new perspective in mind. This brings a new light on the projection of the long-term stability of ${ }^{226} \mathrm{Ra}$ in those tailings. This conclusion only concerns the available, extractable and as such potentially mobile part of ${ }^{226} \mathrm{Ra}$. Our experiments established that much of the ${ }^{226} \mathrm{Ra}$ is in a refractory state and is not chemically available.

Supplementary Materials: The following are available online at http://www.mdpi.com/2075-163X/10/6/497/s1, Figure S1: Liquid:solid ratio used in some sequential extractions, Figure S2: SEM micrograph of barite minerals observed in the C1P3B sample and associated EDS spectra, Table S1: Parameters used in this study to model the sorption on montmorillonite and ferrihydrite and the formation of a (Ba,Ra)SO4 solid-solution, Table S2: Pore water implemented in the model. It is derived from the IPSN, 1984 study, Figure S3: Amount of residual barite after the use of $40 \mathrm{~mL}$ DI water washes on $3.8 \mu \mathrm{mol}$ barite, Figure S4: Distribution of the Ba when $17 \mu \mathrm{mol}$ of barite is put in equilibrium with $40 \mathrm{~mL}$ DI water, pure and with $0.59 \mathrm{~g}$ montmorillonite, Figure S5: Aqueous concentration of Fe species at equilibrium with ferrihydrite and Ba species at equilibrium with barite, Figure S6: Extraction results for experimental data extractions (Chautard et al. [22]) and this study's model optimized and built from bulk data for $\mathrm{Ca}, \mathrm{SO}_{4}, \mathrm{Fe}, \mathrm{Ba}, \mathrm{U}$ and ${ }^{226} \mathrm{Ra}$ per $\mathrm{g}$ of solid for the $\mathrm{C} 1 \mathrm{P} 5 \mathrm{H}$ sample, Figure S7: Extraction results for experimental data extractions (Chautard et al. [22]) and this study's model optimized and built from bulk data for $\mathrm{Ca}, \mathrm{SO}_{4}, \mathrm{Fe}, \mathrm{Ba}, \mathrm{U}$ and ${ }^{226} \mathrm{Ra}$ per $\mathrm{g}$ of solid for the $\mathrm{C} 1 \mathrm{P} 11 \mathrm{~B}$ sample, Figure S8: U and ${ }^{226} \mathrm{Ra}$ initial distribution in the $\mathrm{C} 1 \mathrm{P} 5 \mathrm{H}$ sample according to the direct interpretation of the sequential extractions results and the initial state for the optimum model, Figure S9: U and ${ }^{226} \mathrm{Ra}$ initial distribution in the C1P11B sample according to the direct interpretation of the sequential extractions results and the initial state for the optimum model.

Author Contributions: Conceptualization, M.D.; Investigation, C.C.; Methodology, C.B. and M.D.; Resources, C.C.; Supervision, M.G. and M.D.; Validation, C.C., C.B. and M.D.; Writing-original draft, C.B.; Writing-review and editing, S.S. and P.S. All authors read and approved the final version of the manuscript.

Funding: This research was funded by ORANO Mining, R\&D Department through Envir@Mines.

Acknowledgments: The authors would like to thank E. Tertre (Université de Poitiers) for his help on clay minerals' sorption properties modeling, and P. Reiller (CEA) for his expertise on complexation constants.

Conflicts of Interest: The authors declare no conflict of interest.

\section{References}

1. Ballini, M.; Chautard, C.; Nos, J.; Phrommavanh, V.; Beaucaire, C.; Besançon, C.; Boizard, A.; Cathelineau, M.; Peiffert, C.; Vercouter, T.; et al. A multi-scalar study of the long-term reactivity of uranium mill tailings (Bellezane, France). J. Environ. Radioact. 2020, 218, 106223. [CrossRef] [PubMed]

2. Phan, T.T.; Capo, R.C.; Stewart, B.W.; Graney, J.R.; Johnson, J.D.; Sharma, S.; Toro, J. Trace metal distribution and mobility in drill cuttings and produced waters from Marcellus Shale gas extraction: Uranium, arsenic, barium. Appl. Geochem. 2015, 60, 89-103. [CrossRef] 
3. Van Sice, K.; Cravotta, C.A.; McDevitta, B.; Taskera, T.L.; Landisc, J.D.; Puhra, J.; Warnera, N.R. Radium attenuation and mobilization in stream sediments following oil and gas wastewater disposal in western Pennsylvania. Appl. Geochem. 2018, 98,393-403. [CrossRef]

4. Liu, D.J.; Hendry, M.J. Controls on ${ }^{226}$ Ra during raffinate neutralization at the Key Lake uranium mill, Saskatchewan, Canada. Appl. Geochem. 2011, 26, 2113-2120. [CrossRef]

5. Benĕs, P.; Sedláček, J.; Šebesta, F.; Šandrik, R.; John, J. Method of selective dissolution for characterization of radium and barium in natural and waste waters. Water Res. 1981, 15, 1299-1304. [CrossRef]

6. Tessier, A.; Campbell, P.G.C.; Bisso, M. Sequential extraction procedure for the speciation of particulate trace metals. Anal. Chem. 1979, 51, 844-851. [CrossRef]

7. Schultz, M.K.; Burnetta, W.C.; Inn, K.G.W. Evaluation of a sequential extraction method for determining actinide fractionation in soils and sediments. J. Environ. Radioact. 1998, 40, 155-174. [CrossRef]

8. Perez-Moreno, S.M.; Gazquez, M.J.; Perez-Lopez, R.; Bolivar, J.P. Validation of the BCR sequential extraction procedure for natural radionuclides. Chemosphere 2018, 198, 397-408. [CrossRef]

9. Virtanen, S.; Vaaramaa, K.; Lehto, J. Fractionation of U, Th, Ra and $\mathrm{Pb}$ from boreal forest soils by sequential extractions. Appl. Geochem. 2013, 38, 1-9. [CrossRef]

10. Bacon, J.; Davidson, C. Is there a future for sequential chemical extraction? Analyst 2008, 133, 25-46. [CrossRef]

11. Kheboian, C.; Bauer, C.F. Accuracy of selective extraction procedures for metal speciation in model aquatic sediments. Anal. Chem. 1987, 59, 1417-1423. [CrossRef]

12. Leermakers, M.; Mbachou, B.E.; Husson, A.; Lagneau, V.; Descostes, M. An alternative sequential extraction scheme for the determination of trace elements in ferrihydrite rich sediments. Talanta 2019, 199, 80-88. [CrossRef] [PubMed]

13. Blanco, P.; Vera Tomé, F.; Lozano, J.C. Sequential extraction for radionuclide fractionation in soil samples: A comparative study. Appl. Radiat. Isot. 2004, 610-611, 345-350. [CrossRef] [PubMed]

14. Dodd, J.; Large, D.J.; Fortey, N.J.; Milodowski, A.E.; Kemp, S. A petrographic investigation of two sequential extraction techniques applied to anaerobic canal bed mud. Environ. Geochem. Health 2000, 22, 281-296. [CrossRef]

15. Gleyzes, C.; Tellier, S.; Astruc, M. Fractionation studies of trace elements in contaminated soils and sediments: A review of sequential extraction procedures. Trends Analyt. Chem. 2002, 21, 451-467. [CrossRef]

16. Vandenhove, H.; Vanhoudt, N.; Duquène, L.; Autunes, K.; Wannijn, J. Comparison of two sequential extraction procedures for uranium fractionation in contaminated soils. J. Environ. Radioact. 2014, 137, 1-9. [CrossRef]

17. Ouyang, B.; Renock, D.J.; Ajemigbitse, M. a.; Van Sice, K.; Warner, N.R.; Landisa, J.D.; Feng, X. Radium in hydraulic fracturing wastewater: Distribution in suspended solids and implications to its treatment by sulfate co-precipitation. Environ. Sci. Process. Impacts 2019, 21, 339-351. [CrossRef]

18. Somot, S. Radium, Uranium et Métaux dans les Résidus de Traitement Dynamique, Acide et Alcalin, de Minerais d'uranium. Ph.D. Thesis, Université Henri Poincaré, Nancy, France, 1997.

19. Kersten, M.; Förstner, U. Chemical fractionation of heavy metals in anoxic estuarine and coastal sediments. Water Sci. Technol. 1986, 18, 121-130. [CrossRef]

20. Menozzi, D.; Dosseto, A.; Kinsley, L. Assessing the effect of sequential extraction on the uranium-series isotopic composition of a basaltic weathering profile. Chem. Geol. 2016, 446, 126-137. [CrossRef]

21. Gontier, A. Quantification de l'altération dans les sols par les déséquilibres radioactifs: Approche sur sol total et phases minérales séparées. Ph.D. Thesis, Université de Strasbourg, Strasbourg, France, 2014.

22. Chautard, C.; Beaucaire, C.; Gérard, M.; Roy, R.; Savoye, S.; Descostes, M. Geochemical characterization of U tailings: U and ${ }^{226}$ Ra retention (Bois Noirs Limouzat, France). J. Environ. Radioact. 2020, 218, 106251. [CrossRef]

23. Renock, D.J.; Landis, J.D.; Sharma, M. Reductive weathering of black shale and release of barium during hydraulic fracturing. Appl. Geochem. 2016, 65, 73-86. [CrossRef]

24. Regenspurg, S.; Margot-Roquier, C.; Harfouche, M.; Froidevaux, P.; Steinmann, P.; Junier, P.; Bernier-Latmani, R. Speciation of naturally-accumulated uranium in an organic-rich soil of an alpine region (Switzerland). Geochim. Cosmochim. Acta 2010, 74, 2083-2098. [CrossRef]

25. Shaw, S.A.; Hendry, M.J.; Essilfie-Dughan, J.; Kotzer, T.; Wallschläger, D. Distribution, characterization, and geochemical controls of elements of concern in uranium mine tailings, Key Lake, Saskatchewan, Canada. Appl. Geochem. 2011, 26, 2044-2056. [CrossRef] 
26. Stewart, B.W.; Chapman, E.C.; Capo, R.C.; Johnson, J.D.; Graney, J.R.; Kirby, C.S.; Schroeder, K.T. Origin of brines, salts and carbonate from shales of the Marcellus Formation: Evidence from geochemical and $\mathrm{Sr}$ isotope study of sequentially extracted fluids. Appl. Geochem. 2015, 60, 78-88. [CrossRef]

27. IAEA. Management of NORM Residues; IAEA-TECDOC-1712: Vienna, Austria, 2013; ISBN 978-92-0-142710-6.

28. Meija, J.; Coplen, T.B.; Berglund, M.; Brand, W.A.; De Bièvre, P.; Gröning, M.; Holden, N.E.; Irrgeher, J.; Loss, R.D.; Walczyk, T.; et al. Isotopic Compositions of the Elements 2013 (IUPAC Technical Report). Pure Appl. Chem. 2016, 88, 293-306. [CrossRef]

29. IRSN. Radium-226; Radioprotection: Radionucléides; IRSN: Fontenay-aux-Roses, France, 2014.

30. Karsten, L.; Michalik, B.; Wiegand, J. Availability of radium isotopes and heavy metals from scales and tailings of Polish hard coal mining. J. Environ. Radioact. 2007, 94, 137-150.

31. Rowan, E.L.; Engle, M.A.; Kirby, C.S.; Kraemer, T.F. Radium Content of Oil- and Gas-Field Produced Waters in the Northern Appalachian Basin (USA): Summary and Discussion of Data; U.S. Geological Survey: Reston, VA, USA, 2011.

32. Cuney, M. The extreme diversity of uranium deposits. Miner. Depos. 2008, 44, 3-9. [CrossRef]

33. Cuney, M. World-class unconformity-related uranium deposits: Key factors for their genesis. In Proceedings of the Mineral Deposit Research: Meeting the Global Challenge, Beijing, China, 18-21 August 2005; Springer: Berlin/Heidelberg, Germany, 2005.

34. Cuney, M. Geologic environment, mineralogy, and fluid inclusions of the Bois Noirs-Limouzat uranium vein, Forez, France. Econ. Geol. 1978, 73, 1567-1610. [CrossRef]

35. Pagel, M.; Mao, J.; Bierlein, F.P. Uranium deposits in the Arlit area (Niger). In Mineral Deposit Research: Meeting the Global Challenge; Springer: Berlin/Heidelberg, Germany, 2005.

36. Nirdosh, I.; Muthuswami, S.V.; Baird, M.H.I. Radium in uranium mill tailing - Some observations on retention and removal. Hydrometallurgy 1984, 12, 151-176. [CrossRef]

37. Robertson, J.; Hendry, M.J.; Kotzer, T.; Hughes, K.A. Geochemistry of uranium mill tailings in the Athabasca Basin, Saskatchewan, Canada: A review. Crit. Rev. Environ. Sci. Technol. 2019, 29, 1237-1293. [CrossRef]

38. Fesenko, S.; Carvalho, F.; Martin, P.; Moore, W.S.; Yankovic, T. Radium in the Environment. In The Environmental Behaviour of Radium: Revised Edition; IAEA: Vienna, Austria, 2014; pp. 33-105.

39. Molinari, J.; Snodgrass, W.J. The Chemistry and Radiochemistry of Radium and the Other Elements of the Uranium and Thorium Natural Decay Series. In The Environmental Behaviour of Radium; IAEA Technical Report Series No. 310; IAEA: Vienna, Austria, 1990; Volume 1, pp. 11-56. ISBN 92-0-125090-8.

40. Ames, L.L.; McGarrah, J.E.; Walker, B.A. Sorption or uranium and radium by biotite, muscovite and phlogopite. Clays Clay Miner. 1983, 32, 343-351. [CrossRef]

41. Reinoso-Maset, E.; Ly, J. Study of uranium(VI) and radium(II) sorption at trace level on kaolinite using a multisite ion exchange model. J. Environ. Radioact. 2016, 157, 136-148. [CrossRef] [PubMed]

42. Robin, V.; Tertre, E.; Beaufort, D.; Regnault, O.; Sardini, P.; Descostes, M. Ion exchange reactions of major inorganic cations $\left(\mathrm{H}^{+}, \mathrm{Na}^{+}, \mathrm{Ca}^{2+}, \mathrm{Mg}^{2+}\right.$ and $\left.\mathrm{K}^{+}\right)$on beidellite: Experimental results and new thermodynamic database. Toward a better prediction of contaminant mobility in natural environments. Appl. Geochem. 2015, 59, 74-84. [CrossRef]

43. Nirdosh, I.; Trembley, W.B.; Johnson, C.R. Adsorption-Desorption Studies on the ${ }^{226}$ Ra-Hydrated Metal Oxide Systems. Hydrometallurgy 1990, 24, 237-248. [CrossRef]

44. Sajih, M.; Bryan, N.D.; Livens, F.R.; Vaughan, D.J.; Descostes, M.; Phrommavanh, V.; Nos, J.; Morris, K. Adsorption of radium and barium on goethite and ferrihydrite: A kinetic and surface complexation modelling study. Geochim. Cosmochim. Acta 2014, 146, 150-163. [CrossRef]

45. Bordelet, G.; Beaucaire, C.; Phrommavanh, V.; Descostes, M. Chemical reactivity of natural peat towards U and Ra. Chemosphere 2018, 202, 651-660. [CrossRef]

46. Doerner, H.A.; Hoskins, W.M. Co-precipitation of radium and barium sulfates. J. Am. Chem. Soc. 1925, 47, 662-675. [CrossRef]

47. Curie, M. Radium and the New Concepts in Chemistry. Nobel Lecture. 1911.

48. Lestini, L.; Beaucaire, C.; Vercouter, T.; Ballini, M.; Descostes, M. Role of trace elements in the 226-radium incorporation in sulfate minerals (gypsum and celestite). ACS Earth Space Chem. 2019, 3, 295-304. [CrossRef]

49. USGS Fact Sheet FS-142-99. Naturally Occurring Radioactive Materials (NORM) in Produced Water and Oil-Field Equipment-An Issue for the Energy Industry; USGS: Denver, CO, USA, 1999.

50. Grundl, T.; Cape, M. Geochemical factors controlling radium activity in a sandstone aquifer. Ground Water 2006, 4, 518-527. [CrossRef] 
51. Brandt, F.; Curti, E.; Klinkenberg, M.; Rozov, K.; Bosbach, D. Replacement of barite by a (Ba,Ra)SO $\mathrm{SO}_{4}$ solid solution at close-to-equilibrium conditions: A combined experimental and theoretical study. Geochim. Cosmochim. Acta 2015, 155, 1-15. [CrossRef]

52. Somot, S.; Pagel, M.; Thiry, J. Spéciation du radium dans les résidus de traitement acide de mineai d'uranium de l'Ecarpière (Vendée-France). Compte-rendu de l'Académie des Sciences, Sciences de la terre et des planètes (Earth Planet. Sci.) 1997, 325, 111-118.

53. Abdelouas, A. Uranium mill tailings: Geochemistry, mineralogy, and environmental impact. Elements 2006, 2, 335-341. [CrossRef]

54. Stieff, L.R. The characterization of uranium mill tailings using alpha-sensitive nuclear emulsions. In Proceedings of the 7th Symposium on Management of Uranium Mill Tailings, Low-Level Waste and Hazardous Waste, Fort Collins, CA, USA, 6-8 February 1985.

55. Wagman, D.D.; Evans, W.H.; Parker, V.B.; Schumm, R.H.; Halow, I.; Bailey, S.M.; Churney, K.L.; Nuttall, R.L. The NBS Tables of chemical thermodynamic properties. Selected values for inorganic and C1 and C2 organic substances in SI units. J. Phys. Chem. Ref. Data 1982, 1, 407.

56. Rutten, A.; de Lange, G.J. A novel selective extraction of barite, and its application to eastern Mediterranean sediments. Earth Planet. Sci. Lett. 2002, 198, 11-24. [CrossRef]

57. Van Beek, P. Utilisation de la barytine sédimentaire marine pour les études paléocéanographiques de l'Holocène. Ph.D. Thesis, Université Paris VI, Paris, France, 2001.

58. Eagle, M.; Paytan, A.; Arrigo, K.R.; van Dijken, G.; Murray, R.W. A comparaison between excess barium and barite as indicators of carbon export. Paleoceanogr. Paleoclimatol. 2003, 18, 1021.

59. Sato, A.; Mori, N.; Takakura, M.; Notoya, S. Examination of analytical conditions for trace elements based on the detection limit for EPMA (WDS). JEOL News 2007, 42, 46-52.

60. Batanova, V.G.; Sobolev, A.V.; Magnin, V. Trace element analysis by EPMA in geosciences: Detection limit, precision and accuracy. IOP Conf. Ser. Mater. Sci. Eng. 2018, 304, 012001. [CrossRef]

61. Goulden, W.D. The geochemical distribution of radium-226 in Cluff Lake uranium mill tailings. Master's Thesis, University of Saskatchewan, Saskatoon, SK, Canada, 1997.

62. Bunzl, K.; Kretner, R.; Schramel, P.; Szeles, M.; Winkler, R. Speciation of ${ }^{238} \mathrm{U},{ }^{226} \mathrm{Ra},{ }^{210} \mathrm{~Pb},{ }^{228} \mathrm{Ra}$, and stable $\mathrm{Pb}$ in the soil near an exhaust ventilating shaft of a uranium mine. Geoderma 1995, 67, 45-53. [CrossRef]

63. Landis, J.D.; Sharma, M.; Renock, D.; Niu, D. Rapid desorption of radium isotopes from black shale during hydraulic fracturing. 1. Source phases that control the release of Ra from Marcellus Shale. Chem. Geol. 2018, 496, 1-13. [CrossRef]

64. Gnanapragasam, E.K.; Lewis, B.-A.G. Elastic stain energy and the distribution coefficient of radum in solid solutions with calcium salts. Geochim. Cosmochim. Acta 1995, 59, 5103-5111. [CrossRef]

65. Yoshida, Y.; Nakazawa, T.; Yoshikawa, H.; Nakanishi, T. Partition coefficient of Ra in gypsum. J. Radioanal. Nucl. Chem. 2009, 280, 541-545. [CrossRef]

66. Parkhust, D.L.; Appelo, C.A.J. User's Guide to PHREEQC Version2: A Computer Program for Speciation, Batch-reaction, One Dimensional Transport and Inverse Geochemical Calculations; Water-Resources Investigations; U.S. Departpment of the Interior, USGS: Denver, CO, USA, 1999.

67. Combes, P.; Schmitt, J.M. Etude Hydrologique et Géochimique du Site Minier Des Bois Noirs; CIG Paris School of Mines: Fontainebleau, France, 2006.

68. Tertre, E.; Ferrage, E.; Bihannic, I.; Michot, L.J.; Prêt, D. Influence of the ionic strength and solid/solution ratio on $\mathrm{Ca}$ (II)-for-Na+ exchange on montmorillonite. Part 2: Understanding the effect of the $\mathrm{m} / \mathrm{V}$ ratio. Implications for pore water composition and element transport in natural media. J. Colloid Interface Sci. 2011, 363, 334-347. [CrossRef] [PubMed]

69. Reinoso-Maset, E.; Ly, J. Study of major ions sorption equilibria to characterize the ion exchange properties of kaolinite. J. Chem. Eng. Data 2014, 59, 4000-4009. [CrossRef]

70. Schwertmann, U. Solubility and dissolution of iron oxides. Plant Soil 1991, 130, 1-25. [CrossRef]

71. Dzombak, D.A.; Morel, F.M.M. Surface Complexation Modelling. Hydrous Ferric Oxide; John Wiley \& Sons: Hoboken, NJ, USA, 1990.

72. Nos, J.; Boizard, A.; Peiffert, C.; Cathelineau, M.; Phrommavanh, V.; Descostes, M. Caractérisation et Réactivité des Résidus de Traitement Issus de L'exploitation des Minerais D'uranium en France (Lavaugrasse, Bellezane, Ribière, Cellier); Projet Envir@Mines-PNGMDR 2; AREVA: Paris, France, 2014. 
73. Reiller, P.; Descostes, M. Development and application of the thermodynamic database PRODATA dedicated to the monitoring of mining activities from exploration to remediation. Chemosphere 2020, 251, 126301. [CrossRef]

74. Mahoney, J.; Cadle, S.; Jakubowski, R. Uranyl adsorption onto hydrous ferric oxides-A re-evaluation for the diffuse layer model database. Environ. Sci. Technol. 2009, 43, 9260-9266. [CrossRef]

75. Gossuin, Y.; Colet, J.-M.; Roch, A.; Muller, R.N.; Gillis, P. Cesium Adsorption in Hydrated Iron Oxide Particles Suspensions: An NMR Study. J. Magn. Reson. 2002, 157, 132-136. [CrossRef]

76. Robin, V.; Tertre, E.; Beaucaire, C.; Regnault, O.; Descostes, M. Experimental data and assessment of predictive modeling for radium ion-exchange on beidellite, a swelling clay mineral with a tetrahedral charge. Appl. Geochem. 2017, 85, 1-9. [CrossRef]

77. Tertre, E. Détermination d'une Base de Données Opérationnelle Relative à L'adsorption sur les Minéraux Argileux; AREVA: Paris, France, 2017.

78. Pabalan, R.T.; Turner, D.R. Uranium(6+) sorption on montmorillonite: Experimental and surface complexation modeling study. Aquat. Geochem. 1997, 2, 203-226. [CrossRef]

79. Tertre, E.; Beaucaire, C.; Coreau, N.; Juery, A. Modeling of Zn sorption onto clayey sediments using a multi-site and multi-component ion-exchange model. Appl. Geochem. 2009, 24, 1852-1861. [CrossRef]

80. Curti, E.; Fujiwara, K.; Iijima, K.; Tits, J.; Cuesta, C.; Kitamura, A.; Glaus, M.A.; Müller, W. Radium uptake during barite recrystallization at $23 \pm 2{ }^{\circ} \mathrm{C}$ as a function of solution composition: An experimental ${ }^{133} \mathrm{Ba}$ and ${ }^{226}$ Ra tracer study. Geochim. Cosmochim. Acta 2010, 74, 3553-3570. [CrossRef]

81. Langmuir, D.; Reise, A.C. The thermodynamic properties of radium. Geochim. Cosmochim. Acta 1985, 49, 1593-1601. [CrossRef]

82. Zhang, T.; Gregory, K.; Hammack, R.W.; Vidic, R.D. Co-precipitation of radium with barium and strontium sulfate and its impact on the fate of radium during treatment of produced water from unconventional gas extraction. Environ. Sci. Technol. 2014, 48, 4596-4603. [CrossRef] [PubMed]

83. Chuiton, G.; Sanchez, B. Etude de la Composition Chimique de l'eau Interstitielle des sédiments du Grand Bassin du Forez; Gestion des résidus du Forez-Analyses sur produits carottés; Institut de Protection et de Sûreté Nucléaire-CEA: Fontenay-aux-Roses, France, 1984.

84. Blount, C. Barite solubilities and thermodynamic quantities up to $300^{\circ} \mathrm{C}$ and 1400 bars. Am. Mineral. 1977, 62, 9-10.

85. Atun, G.; Bascetin, E. Adsorption of barium on kaolinite, illite and montmorillonite at various ionic strengths. Radiochimica Acta 2003, 91, 223-228. [CrossRef]

86. Eylem, C.; Erten, H.N.; Göktürk, H. Sorption of barium on kaolinite, montmorillonite and chlorite. Analyst 1989, 114, 351-353. [CrossRef]

87. Zhang, P.; Brady, P.; Arthur, S.; Zhou, W.Q.; Sawyer, D.; Hesterberg, D. Adsorption of barium (II) on montmorillonite: An EXAFS study. Colloids Surf. A Physicochem. Eng. Asp. 2001, 190, 239-249. [CrossRef]

88. COGEMA. Site des Bois Noirs Limouzat-Situation Actuelle et Etudes d'hypothèses d'améliorations Pour Assurer Une Sécurité Durable; COGEMA: Paris, France, 1998.

89. Sardini, P.; Angileri, A.; Descostes, M.; Duval, S.; Oger, T.; Partier, P.; Rividi, N.; Siitari-Kauppi, M.; Toubon, H.; Donnard, J. Quantitative autoradiography of alpha particle emission in geo-materials using the Beaver ${ }^{\mathrm{TM}}$ system. Nucl. Instrum. Methods Phys. Res. A 2016, 833, 15-22. [CrossRef]

90. Angileri, A.; Sardini, P.; Donnard, J.; Duval, S.; Lefeuvre, H.; Oger, T.; Partier, P.; Rividi, N.; Siitari-Kauppi, M.; Toubon, H.; et al. Mapping ${ }^{238} \mathrm{U}$ decay chain equilibrium state in thin sections of geo-materials by digital autoradiography and microprobe analysis. Appl. Radiat. Isot. 2018, 140, 228-237. [CrossRef]

91. Angileri, A.; Sardini, P.; Beaufort, D.; Amiard, G.; Beaufort, M.F.; Nicolai, J.; Siitari-Kauppi, M.; Descostes, M. Mobility of daughter elements of ${ }^{238} \mathrm{U}$ decay chain during leaching by In Situ Recovery (ISR): New insights from digital autoradiography. J. Environ. Radioact. 2020, 220-221, 106274. [CrossRef]

92. Billon, S.; Sardini, P.; Angileri, A.; Beaucaire, C.; Parneix, J.-C.; Siitari-Kauppi, M.; Descostes, M. Quantitative imaging of ${ }^{226}$ Ra ultratrace distribution using electronic autoradiography: case of doped celestines. J. Environ. Radioact. 2020, 217, 106211. [CrossRef] [PubMed]

(C) 2020 by the authors. Licensee MDPI, Basel, Switzerland. This article is an open access article distributed under the terms and conditions of the Creative Commons Attribution (CC BY) license (http://creativecommons.org/licenses/by/4.0/). 